Academic Platform Journal of Engineering and Science

journal homepage: $\underline{\text { htpp://apjes.com/ }}$

\title{
Döküm Sanayinde Süreç Tabanlı Temel Gösterimleri ile İstatistiksel Süreç Kontrolü
}

\author{
*11Kenan Orçanlı \\ ${ }^{1}$ Toros Üniversitesi, İktisadi İdari ve Sosyal Bilimler Fakültesi, İşletme, kenan.orcanli@toros.edu.tr, \\ Araştırma Makalesi \\ Geliş Tarihi: 14.04.2020 \\ Kabul Tarihi: 06.12.2020
}

\section{$\ddot{O} z$}

Döküm sanayinde süreç kontrolünde, kalite karakteristiği olarak genellikle üretilen ürünün çap, kalınlık, yoğunluk gibi özellikleri ele alınmaktadır. Söz konusu kalite karakteristikleri, genellikle kalite kontrol grafikleri ile izlenerek süreci etkileyen özel nedenlerin varlığı ortaya konulmaya çalışılmaktadır. Ancak döküm sanayinde kalite karakteristikleri olarak üretilen ürünün özellikleri yerine ürünü oluşturan elementlerin oranları da kabul edilebilmektedir. Çünkü ürünün içeriğini oluşturan elementlerin oranlarının, belirli sınırlar arasında olması istenmekte ve genellikle değişkenlik göstermektedir. Kalite karakteristikleri olarak seçilebilen metal oranları, ürünün özelliklerinde olduğu gibi kalite kontrol grafikleri ile izlenebilmekte ancak kontrol dışı sinyallerin yorumlanması yeterince yapılamamaktadır. Dolayısıyla sorunun çözümünde kalite kontrol grafiklerinin yerine literatürde yer alan süreç tabanlı temel gösterimleri metodu kullanılabilir. Yapılan literatür araştırması neticesinde, süreç tabanlı temel gösterimleri metodunun, imalat sanayinde geometrik sapmaların modellenmesinde başarılı bir şekilde kullanıldığ ancak proses (kimya, petro-kimya, döküm vb.) endüstrilerinde ve birbiriyle ilişki içinde olan kalite karakteristiklerin bulunduğu çok değişkenli endüstriyel üretim süreçlerinde uygulamasının olmadığı tespit edilmiştir. Bu kapsamda yapılan bu çalışmanın amacı, döküm sanayinde süreç kontrolünde, metal alaşım oranlarının kalite karakteristiği olarak kullanılabileceğini ve yine süreç tabanlı temel gösterimleri metodunun uygulanabileceğini göstermektir. Çalışmada kullanılan veriler, 01 Ocak 2015-31 Mart 2015 tarihleri arasında Kırıkkale ilinde yerleşik Makine ve Kimya Endüstrisi Kurumu'na bağlı Pirinç Fabrikası Müdürlüğünün üretim biriminden elde edilmiştir. Kontrol grafiklerinin oluşturulmasında MINITAB paket programında yer alan modül kullanılmıştır. Çalışmanın sonunda; döküm sanayinde uygulanan süreç kontrolünde, kalite karakteristiği olarak üretilen ürünü oluşturan element oranlarının da seçilebileceği ve bu şekilde seçilen kalite karakteristiklerin süreç tabanlı temel gösterimleri yöntemi ile izlenerek olumlu sonuçlar elde edilebileceği tespit edilmiştir. Çalışmada elde edilen bulgu ve sonuçların gerek ulusal gerekse uluslararası literatüre hem teorik ve hem de pratik katkı sağlayacağı düşünülmektedir.

Anahtar Kelimeler: Döküm, Pirinç, Süreç Tabanlı Temel Gösterimleri

\section{A Statistical Process Control with Process Oriented Basis Representation in Casting Industry}

\author{
${ }^{*}$ Kenan Orçanlı \\ ${ }^{1}$ Toros University, Faculty of Economics Administrative and Social Sciences, Department of Business, \\ kenan.orcanli@toros.edu.tr
}

\begin{abstract}
In process control in the casting industry, the features of the product, such as diameter, thickness, density, are generally considered as quality characteristics and assignable causes affecting the process is tried to be determined by monitoring these quality characteristics in the quality control charts. However, instead of the features of the producing product as quality characteristics in the casting industry, the proportions of the elements that make up the product can also be accepted. Because the proportions of the elements that make up the product are desired to be within certain limits within the product and these generally vary. In addition, metal ratios, which can be selected as quality characteristics, can be monitored with quality control charts as in the properties of the product, but interpretation of out-of-control signals may not be sufficient. Therefore, in the solution of the problem, instead of quality control graphics, the process-oriented basis representations method in the literature can be used. As a result of the research in the literature, it has been determined that the process-oriented basis representations method has been used successfully in the modeling of geometric deviations in the manufacturing industry, but it is not applied
\end{abstract}

${ }^{* 1}$ Sorumlu Yazar: Dr. Öğr. Üyesi Kenan Orçanlı, Toros Üniversitesi, Mersin, kenan.orcanli@toros.edu.tr, 0.531.2279873 $\mathrm{Bu}$ çalışma, doktora tez çalışmasından üretilmiş bir çalışmadır. 
in the process (chemistry, petro-chemistry, casting, etc.) industries, and in multivariate industrial production processes with interrelated quality characteristics. In this content, the aim of this study was is to show that metal alloy ratios can be used as quality characteristics and the process-oriented basis representations method can be applied in process control in the casting industry. The data used in the study were obtained from the production process of Brass Factory Directorate of Mechanical and Chemical Industry Company in Kirıkkale province between 01 January 2015 and 31 March 2015. The module in the Minitab package program was used to create the control charts. At the end of the study, it has been determined that in the process control in the casting industry, the element ratios that make up the product produced as quality characteristics can be selected and positive results can be obtained by monitoring the quality characteristics selected in this way with the process-oriented basis representations method. It is evaluated that the results obtained in the study will contribute both to the domestic and foreign literature theoretically and to the quality control applications in terms of practicality in the casting industry.

Keywords: Casting, Brass, Process Oriented Basis Representation.

\section{GİRIŞ}

Üretim süreçlerinde kullanılan yöntemlerden birisi, döküm yöntemidir. Bilim insanları ve mühendislerin katkılarıyla kalıp malzemeleri, kalıplama yöntemleri, eritme ocakları, döküm malzemeleri gibi alanlarda sürekli geliştirilen döküm yöntemi, günümüzde de en yaygın olarak kullanılan ve gelişen bir üretim yöntemi haline gelmiştir. Literatürde döküm yönteminin çeşitli tanımları bulunmasına rağmen, genel olarak "metal üretme firınlarından elde edilen eriyik haldeki metalin kullanım amacına göre gerekli şekil verilerek katılaştırılması olayı" şeklinde tanımlanabilir [1,2]. Her ne kadar döküm yöntemi, metallerin sıcak ocaklarda eritilip eriyik haline getirilip kalıplara dökülmesi şeklinde tanımlansa bile birçok aktiviteyi kapsamaktadır.

Döküm sanayisindeki üretim süreci faaliyetleri, literatürde genellikle saf ve hurda malzemelerin harmanlanması, oluşturulan şarjların eritilmesi ve sıvı haldeki eriyin kalıplanması şeklinde olmak üzere üç aşamada ele alınmaktadır [3-7].

Döküm yönteminin birinci aşaması olan saf ve hurda malzemelerin harmanlanması aşamasında, üretilen ürünün hammaddesi olan saf metallere çeşitli metal ve ametaller belli oranlarda karıştırılarak şarjlar (harmanlar) elde edilmektedir. Döküm yönteminin ikinci aşaması olan oluşturulan şarjların eritilmesi sürecinde, şarjlar yüksek sıcaklıkta eritilerek sıvı halde eriyik haline getirilmektedir. Döküm yönteminin üçüncü ve son aşaması olan sıvı haldeki eriyin kalıplanması sürecinde ise istenilen şeklin oluşturulması için sıvı eriyik daha önce hazırlanmış kalıplara dökülerek soğutulmakta ve istenilen özelliklerde ürün elde edilmektedir [1.2].

Endüstride döküm yöntemi ile üretilen alüminyum, pirinç ve altın alaşımları gibi birçok ürün bulunmaktadır [8]. Pirinç alaşımı, yukarıda en genel hali ile anlatılan döküm yöntemi ile üretilen ürünlerden bir tanesi olup günümüzde birçok üretim sürecinde oldukça yaygın olarak kullanılmaktadır [9].

Pirinç, doğada tabii olarak bulunmayıp; bakır $(\mathrm{Cu})$, çinko $(\mathrm{Zn})$ ve gerekli hallerde kurşun $(\mathrm{Pb})$ gibi metallerden oluşan ve döküm yoluyla üretilen bir alaşımdır. Diğer bir deyişle pirinç, $\mathrm{Cu}$ ve $\mathrm{Zn}$ 'nin birlikte yaptığı alaşıma verilen isimdir [10]. Pirinç alaşımı, $\mathrm{Cu}$ ve $\mathrm{Zn}$ elementlerinin farklı oranlarda birleşmesi sonucunda oluşmaktadır. Herhangi bir alaşımın elde edilmesinde, bu şekilde elementlerin değişik oranlarda birleşme olayına faz denilmektedir. Literatürde faz kavramı alfa, beta ve gama olmak üzere üç ayrı gruba ayrılmaktadır. $\mathrm{Cu}$ ve $\mathrm{Zn}$ elementleri birleşerek pirinç alaşımını oluştururken çok faz meydana getirmektedir [11]. Öncelikle \%37'den az Zn içeren pirinç alaşımına "alfa tipi faza sahip pirinç çeşidi" denilmektedir. Bu fazdaki pirinç, merkezli kübik yapıda bir yüzeye sahip olup kolayca soğuk işleme tabi tutulabilmekte ve kübik yapıya sahip olması dolayısıyla talaşsız olarak imal edilebilmektedir. Alaşımda $\mathrm{Zn}$ içeriğinin artması ile mukavemette de artış sağlanmaktadır. Alfa fazı, iyi mukavemet ve süneklik özelliklerini bir arada bulundurmaktadır [11-13]. İkinci olarak \%32 ile \%37 arasında Zn içeren pirinç alaşımına "beta tipi faza sahip pirinç çeşidi” denilmektedir. Beta fazındaki pirinç, hacim merkezli kübik kristal yapıda olup sıcak işlem kabiliyeti en yüksek olan pirinç türüdür. Yine $\% 37$ ile $\% 45 \mathrm{Zn}$ içeren pirinç alaşımlarında, alfa ve beta fazları bir arada bulunabilir [11-13]. Pirinç alaşımında görülen diğer bir faz çeşidi de gama fazıdır. Bu faz yapısına sahip pirinç alaşımının içinde $\% 45$ 'ten fazla $\mathrm{Zn}$ bulunmaktadır. Gama fazının endüstriyel kullanım alanı bulunmamaktadır. Çünkü bünyesinde sert $\mathrm{Cu}_{2} \mathrm{Zn}_{3}$ kristallerini barındırdığından dolayı ne sıcak ne de soğuk olarak işlenebilmektedir [11,12].

Saf maddeler olan $\mathrm{Cu}$ ve $\mathrm{Zn}$ elementlerinin yanında pirinç üretiminde, maliyetinin düşük olması nedeniyle hurda malzemeler de kullanılmaktadır. Dolayısıyla pirinç üretim sürecinde kullanılan girdiler, saf ve hurda malzemelerdir. Hurda malzemelerin içinde saf elementlerin yanında Kalay (Sn), Antimuan (Sb), Nikel (Ni), Demir (Fe), Alüminyum (Al) gibi çeşitli elementler de bulunmaktadır. Bu hurdaların içinden gelen bu elementlere empürite (safsızlık) adı verilmektedir $[1,2]$.

Pirinç alaşımları, içerdikleri element yüzdelerine göre farklılık göstermekte ve farklı olarak isimlendirilmektedir. Küresel standart olarak belirlenmiş ve DIN17660 olarak adlandırılmış on dokuz çeşit pirinç alaşımı bulunmaktadır $[1,2]$. Bu çalışmada örnek olarak DIN17660 pirinç alaşımı çeşitlerinden biri olan MS58 pirinç alaşımı seçilmiştir. $\mathrm{Bu}$ kapsamda MS58 cinsi pirinç alaşımının detaylı içeriği aşağıdaki Tablo 1'de verilmiştir. Oranlar, ağırlık cinsinden yüzde değerleridir. 
Tablo 1. MS58 Pirinç Alaşımının İçeriği

\begin{tabular}{|l|c|c|}
\hline \multicolumn{3}{|c|}{ MS58 } \\
\hline & Alt Spesifikasyon Değeri (\%) & Üst Spesifikasyon Değeri (\%) \\
\hline $\mathrm{Cu}$ & 57 & 59 \\
\hline $\mathrm{Pb}$ & 2.5 & 3.5 \\
\hline $\mathrm{Fe}$ & 0 & 0,5 \\
\hline $\mathrm{Sn}$ & 0 & 0,4 \\
\hline $\mathrm{Al}$ & 0 & 0,1 \\
\hline $\mathrm{Ni}$ & 0 & 0,5 \\
\hline $\mathrm{Sb}$ & 0 & 0,02 \\
\hline Diğer & 0 & 0,3 \\
\hline $\mathrm{Zn}$ & \multicolumn{2}{|c|}{ Geri kalan } \\
\hline
\end{tabular}

Yukarıdaki Tablo 1'in ilk sütununda MS58 cinsi pirinç alaşımının içinde bulunan elementler ve diğer sütunlarında da bu elementlerin alt ve üst değerleri yer almaktadır. Tablo l'in birinci ve dokuzuncu satırında, MS58 cinsi pirinç alaşımını oluşturan ana elementler yani $\mathrm{Cu}$ ve $\mathrm{Zn}$ elementleri yer almaktadır. Tablo 1'in ikinci, üçüncü, dördüncü, beşinci, altıncı ve yedinci satırında, MS58 cinsi pirinç alaşımına çeşitli özellikler kazandırmak için eklenmesi gereken bazı diğer elementler yer almaktadır. Kü̧̈ük oranlarda katılan bu elementler, üretilen malzemeye işlenebilirlik özelliği kazandırılabilmesi için önemlidir. Tablo 1'deki diğer satırı ise oranları çok küçük olan ve alaşım için bir önem arz etmeyen empüritelerin toplamını ifade etmektedir.

En küçük ve en büyük oranlarının dışına çıkan bir element, alaşımın yapısını bozmakta ve bu durumda pirinç hatalı kabul edilmektedir. Üretim sürecinde hatalı üretilen pirinç alaşımı, diğer hurda malzemelerle harmanlanarak üretim sürecine tekrar sokulmaktadır. Ancak metal karışımı eriyik halde ise eriyik içine gerekli miktarda saf $\mathrm{Cu}$ ve saf $\mathrm{Zn}$ elementi karıştırılmakta ve böylece eriyiğin içindeki element oranlarının referans değerler arasında olması için müdahalede bulunulmaktadır [14]. Eriyik içindeki element oranları istenilen oranlarda ise eriyik kalıplara dökülerek şekil verilmesi aşamasına geçilmektedir.

\section{DÖKÜM SANAYISINININ SÜREÇLERININ KALITE KONTROLÜ \\ ÜRETIM}

Herhangi bir üretim sürecinde kalite kontrolünde kalite karakteristiklerine göre gerekli değerlendirmeler yapılmaktadır. Ortaya konulan kalite karakteristiklerinden bazıları kalite uzmanlarına daha fazla bilgi sağlayabilmektedir. Bu kalite karakteristikleri de literatürde "kritik kalite karakteristikleri" olarak adlandırılmaktadır [15]. Kritik kalite karakteristikleri, bir sürecin kontrol altında olup olmadığının en önemli değişkenleri olarak kabul edilmektedir.

Döküm sürecinde istenilen kompozisyon ve şekilde bir alaşım üretmek amacıyla diğer sektörlerde olduğu gibi kritik kalite karakteristikleri belirlenerek kalite kontrolü uygulanmaktadır. Döküm sürecinde yapılan kalite kontrolü genellikle üç aşamada yapılmaktadır. Birinci aşamada; eriyik haline gelen metal dinlendirme ocağına alınmadan önce içindeki element oranlarının belli oranlarda olması gerekmektedir. Element oranları, eriyik içinde bulunan metallerin ağıllığının toplam eriyik ağırlığına bölünmesi ile elde edilen yüzde değerlerdir. Bir metalin kalitesi bu elementlerin yüzde değerlerine bakılarak yapılmakta ve istenen referans değerleri dişında herhangi bir değer tespit edilmesi durumunda gerekli müdahale yapılmaktadır (İlk kontrol) [16]. İkinci aşamada; farklı indüksiyon ocaklarından gelen eriyik, dinlendirme ocağında karıştırılmakta ve birinci aşamada yapılan işlem tekrarlanmaktadır (İkinci kontrol). Üçüncü aşamada; dinlendirme ocağından gelen eriyik istenen özelliklerde kalıplara dökülerek soğutulmakta ve böylece nihai ürün veya nihai ürün için gerekli olan hammadde elde edilmektedir. Müteakiben elde edilen nihai ürünün veya nihai ürün için gerekli olan hammadde halindeki alaşımın daha çok fiziki özelliklerine veya boyutlarına bakılarak yapılmaktadır [7]. Bu kapsamda pirinç alaşımı üretim sürecinde kalite karakteristikleri üretilen ürünün çap, kalınlık, sertlik gibi özellikler olmaktadır.

Döküm sürecinde yapılan işler kapsamında birinci ve ikinci kalite kontrolünde, eriyik haldeki pirinç alaşımlarından her defasında belli periyotlarla kontrol amaçlı numune alınmakta ve bu numuneler spektral analize tabi tutulmaktadır. Spektral analizin yapıldığ ölçüm aleti spektrometre olarak da adlandırılmaktadır. Spektrometreler 1şığı spektral olarak dalga boylarına ayıran elektriksel sinyallere dönüştürerek belli bir referansa göre materyal analizi yapabilen cihazlardır. Spektral analiz cihazları ile pik ve sfero döküm, düşük alaşımlı çelikler, paslanmaz çelikler, mangan çelikleri, otomat çelikleri, etial alaşımları, alüminyum alaşımları, saf alüminyum, bakır, pirinç, bronz, saf çinko analizleri gerçekleştirilebilmektedir [17]. Spektrometre, kısa zamanda ve oldukça hassas yapılan ölçümleri ekranda göstermektedir.

Spektral analiz sonunda karışımın içerisindeki elementlerin ağırlık yüzdeleri ölçülerek elde edilen sonuçların DIN standartlarına uygunluğu kontrol edilmektedir. Elde edilen herhangi bir elementin oranı alt referans değerinin altında çıkmışsa standardı sağlamak için o maddeden gerekli miktar ocağa eklenmektedir. Eğer element oranı üst referans sınırının üzerinde çıkmışsa; öncelikle saf $\mathrm{Zn}$ ve bu Zn'nin eklenmesiyle oranı alt referans sınırının altına inecek olan elementten gerekli miktar ocağa ilave edilmektedir. Ocakta farklı bir ürünün dökümüne geçilecekse bir önceki ürünün dökümünden belli bir miktar ocakta kaldığı için ocağa saf $\mathrm{Cu}$ veya $\mathrm{Zn}$ ilave edilmektedir. Yeni ürünün $\mathrm{Cu}$ oranı bir öncekinden yüksek ise saf $\mathrm{Zn}$, düşük ise saf $\mathrm{Cu}$ ilave edilerek ocaktaki karışımın empürite oranları yeni ürünün seviyesine çekilmektedir [17, 18]. Bu kapsamda istenen element seviyesinin ayarlanması için uygulanan formül, Denklem-1'de gösterilmiştir.

$\%$ İstenen Element $=\frac{\mathrm{X}_{1} * \mathrm{M}_{1}+\mathrm{X}_{2} * \mathrm{M}_{2}}{\mathrm{M}_{1}+\mathrm{M}_{2}}$

Bu denklemde:

$X_{1}$ : Ocak içerisinde o anda ergimiş halde bulunan istenen element \%si, 
$X_{2}$ : Ocă̆a ilave edilecek hammaddenin içeriğinde bulunan istenen element \%si,

$M_{1}$ : Ocak içerisinde o anda bulunan sivı metal miktarl,

$M_{2}$ : Ocağa ilave edilecek hammadde miktarl.

Yukarıda açıklanan kalite kontrolü ile ilgili olarak nihai ürünün kalitesini aynı seviyede tutmak veya diğer bir deyişle üretim sürecinin değişkenliğini kontrol altında tutmak için genellikle üretilen ürünün özellikleri (ürünün çapı, akışkanlığı, boyu, ağırlığı vb.) izlenmektedir [19]. Ancak bu durum, nihai ürünün özellikleri takip edildiği için uzun zaman almakta, fazla maliyetli olmakta ve aynı zamanda üretim kapasitesini düşürebilmektedir. Aslında bu durum kalite kontrol literatüründe kabul örneklemesine benzer bir olay olarak değerlendirilebilir. İstatistiksel kalite kontrolünde önemli olan ürün henüz üretim sürecinde iken gerekli önlemi alarak süreci etkileyen özel faktörlerin belirlenmesi ve gerekli tedbirin alınmasıdır. Dolayısıyla söz konusu amaç çerçevesinde "üretilen ürünü oluşturan element oranları" da kalite karakteristiği olarak kabul edilebilir [15].

Günümüzde kritik kalite karakteristiklerini izlemek ve karar vermek amaciyla genellikle kalite kontrol grafikleri kullanılmaktadır. Tek değişkenli süreçlerde kontrol grafikleri, $S$ ve $R$ ile gösterilen standart sapma ve değişim aralığı istatistiklerine dayalı olarak tasarlanırken çok değişkenli süreçlerde ise kontrol grafikleri, örneklem kovaryans matrisinden $(S)$ hesaplanan genelleştirilmiş varyansa (örneğin; $|S|$ [20], $\log |S|[21],|S|$ [22]) dayalı olarak dizayn edilmektedir. Ayrıca, bunların yanında değişimin tespit edilmesinde çok değişkenli süreçler için Lowry, Woodall, Champ ve Rigdon (1992) [23] ve Reynolds ve Cho (2006) [24] tarafından önerilen Çok Değişkenli Üssel Ağırlıklı Hareketli Ortalama (Multivariate Exponentially Weighted Moving Average (MEWMA)) kontrol grafiği ile Hotelling $\mathrm{T}^{2}$ [25] kontrol grafiği de kullanılmaktadır. Her ne kadar Hotelling $T^{2}$ kontrol grafiği ile izlenen istatistik değeri, kalite karakteristiklerin ortalama değerlerinden elde edilse de yapılan hesaplamada bu değerler arasında var olan kovaryans yapısının da dikkate alınmasından dolayı bu kategoride değerlendirilebilmektedir.

Çok değişkenli kontrol grafiklerinin "değişken sayısının 10'un üzerinde olması durumunda" etkisi azalmaktadır [26]. Literatürde günümüze kadar birçok kontrol grafiği önerilmiştir, ancak bütün önerilen kontrol grafiklerinin temeli Lowry, Woodall, Hotelling (1947) [25], Lowry, Woodall, Champ ve Rigdon (1992) [23], Reynolds ve Cho (2006) [24] tarafindan önerilen kontrol grafiklerine dayanmaktadır.

Özel (2005) [1] ile Özel ve Birgören (2005) [2] tarafından söz konusu çok değişkenli kontrol grafiklerinden Hotelling $T^{2}$ kontrol grafikleri ile yapılan bir çalışmada kalite karakteristiği olarak metal oranları izlenerek üretim sürecinin kontrolü sağlanmaya çalışılmıştır. Çalışmalarda üretim sürecini etkileyen özel bir durumun varlığ (Mason-Young-Tracy) ayrıştırma yöntemi kullanılarak çözüm bulunma yoluna gidilmiştir. Ancak kontrol dışı sinyal durumu değişkenlere bağlı olarak yorumlanmaya çalışılmış ve hata kaynağı ile ilgili kesin bir sonuca gidilemediği tespit edilmiştir.

Süreç değişkenliği, yukarıda sayılan tekniklerin yanında gelişen teknolojik gelişmeler neticesinde temeli alt uzay örnekleme yöntemine (subspace projection metot) dayanan çeşitli yöntemler ile de tespit edilebilmektedir. Bu yönteme Runger (1996) [27] tarafindan önerilen $U^{2}$ kontrol grafiği, Barton ve Gonzalez-Barreto (1996) [28] tarafindan önerilen süreç tabanlı temel gösterimleri (proses oriented basis representation), Mantripragada ve Whitney (1999) [29], Jin ve Shi (1999) [30] ve Ding, Ceglarek ve Shi (2000) [31] tarafından önerilen montaj işlemleri için fiziksel modeller (physical models for assembly processes) ve Zhou, Huang ve Shi (2003) [32], Djurdjanovic ve Ni (2001) [33] ve Huang, Zhou ve Shi (2000) [34] tarafindan önerilen işleme süreci için durum uzayı modelleri (the state space models for machining processes) olan çalışmalar da bu kapsamda değerlendirilebilir. $\mathrm{Bu}$ çalışmalarda önerilen modellerin hepsi doğrusal modellerdir ve bu modellerde elde edilen parametreler kontrol grafikleri ile izlenmekte ve parametreler çoğunlukla en küçük kareler metodu veya ağırlıklı en küçük kareler metodu kullanılarak bulunmaktadir.

\section{ARASTIRMANIN AMACI VE ÖNEMI}

Yerli ve yabancı literatürde yapılan araştırma neticesinde döküm süreçlerinde değişkenliği belirlemek amacıyla genellikle üretilen ürünlerin özelliklerinin kalite karakteristiği olarak ele alındığ 1 ancak bunun yerine ürünün kompozisyonunu oluşturan element oranlarının da kalite karakteristiği olarak kabul edilebileceği tespit edilmiştir.

Söz konusu kalite karakteristiği olarak kabul edilen element oranlarının kalite kontrol grafikleri ile izlenebileceği, ancak yapılan yorumlamalarda hata kaynakları ile ilgili olarak doyurucu bilgilere ulaşılamayacağı ve kalite karakteristikleri sayısının fazla olması durumunda kalite kontrol grafiklerinin etkinliğinin azaldığı (Montgomery, 2013) [26] bilgisine ulaşılmıştır. Bunun üzerine hata kaynaklarını ortaya koyan farklı bir yönteme ihtiyaç duyulmuş ve süreç tabanlı temel gösterimleri metodunun kullanılmasına karar verilmiştir. Ayrıca süreç tabanlı temel gösterimleri metodunun imalat sanayinde geometrik sapmaların modellenmesinde başarılı bir şekilde kullanılmış, ancak proses (kimya, petro-kimya, döküm vb.) endüstrilerinde ve birbiriyle ilişki içinde olan kalite karakteristiklerin bulunduğu çok değişkenli endüstriyel üretim süreçlerinde uygulamasının olmadığı tespit edilmiştir. Dolayısıyla uygulanan yöntem yeni bir alanda ve birbiriyle ilişkili kalite karakteristiklerinin bulunduğu çok değişkenli bir üretim sürecinde ilk defa uygulanmış ve yerli ve yabancı literatüre katkı sağlamıştır. Bu kapsamda yapılan çalışmanın amacı, döküm süreçleri ile ilgili olarak yapılan kalite kontrollerinde üretilen ürünlerin iç kompozisyonlarındaki element oranlarının da kalite karakteristiği olarak ele alınabileceği ve söz konusu süreç değişkenliğini etkileyen özel nedenleri belirlemede süreç 
tabanlı temel gösterimleri yönteminin kullanılabilirliğini göstermektir.

\section{YÖNTEM}

\subsection{Araştırmanın Yapıldığı Üretim Süreci ve Uygulama Așamaları}

Yapılan araştırma, Kırıkkale ilinde bulunan MKEK Pirinç Fabrikası Müdürlügüu üretim süreçlerinde beş aşama halinde yapılmıştır. Çalışmanın;

- Birinci aşamasında (1. Adım); pirinç üretim sürecinde araştırmanın amacı kapsamında belirlenen kalite değişkenleri ve parametreleri tanımlanmıştır,

- İkinci aşamasında (2.Adım); süreç tabanlı temel gösterimleri metodunda kullanılan modellerden araştırmaya uyan modelin seçimi yapılmıştır,

- Üçüncü aşamasında (3. Adım); süreç tabanlı temel gösterimleri metodunda bağımlı değişken olarak kullanılan kalite vektörü oluşturulmuştur,

- Dördüncü aşamasında (4. Adım); pirinç üretim sürecinde süreç değişkenliğine etki edebilecek hata kaynakları tespit edilmiş ve bu hata kaynaklarına bağlı olarak kullanılan modelde bağımsız değişkenler süreç tabanlı temel elemanlarının bulunduğu hata matrisi (hata matrisinde her bir sütun bir hata kaynağını temsil etmekte olup aynı zamanda her biri kurulan matematiksel modelde bağımsız değişkenleri temsil etmektedir.) oluşturulmuştur,

- Beşinci aşamasında (5. Adım); kurulan modelin varsayımları ile ilgili çoklu doğrusallık olup olmadığı kontrol edilmiştir,

- Altıncı aşamasında (6. Adım); çoklu doğrusallık durumuna göre matematiksel modelde hata kaynaklarının büyüklüğünü temsil eden parametreler hem tek değişkenli kontrol grafiklerinden $I, M$ ve $E W M A$ kontrol grafikleri ile ve hem de çok değişkenli kontrol grafiklerinden Hotelling $T^{2}$ kontrol grafiği ile takibi yapılarak yorumlar yapılmıştır.

\subsection{Araştırma Yöntemi (Süreç Tabanlı Temel Gösterimleri (STTG))}

Günümüzde üretim sistemlerinde veri toplanması için otomatik ve yeni teknolojiyle donatılmış sistemler geliştirilmiştir. Otomatik veri toplama araçları ve sayısal analiz yöntemleri çok hızlı ve masrafsız şekilde çok değişkenli ölçüm yapmakta ve birçok endüstride üretimdeki ölçüm miktarını çoğaltmaktadır. Örneğin imalat sanayinde, kullanım kolaylığı arttırılmış hassas mastar ve ölçüm aletleri, üç-boyutlu koordinat ölçüm cihazları, kameralara veya lazer teknolojisine dayalı optik sistemler, bilgisayarla bütünleşik şekilde hata teşhisinde kullanılmaktadır [28, 35-37]. Kamera sistemleri hem talaşlı hem de elektronik imalat fabrikalarında, üç-boyutlu koordinat ölçüm cihazları ise genellikle talaşlı imalat fabrikalarında hızla yaygınlaşmaktadır. Bu durum şirketlerin elinde kompleks ve içerisinde birçok gizli bilginin bulunduğu çok sayıda veri kümelerini yani kalite karakteristiklerini ortaya çıkarmaktadır [38].

Günümüzde kalite karakteristiği sayısının ve bu kalite karakteristiklerindeki gözlem sayısının artması geleneksel çok değişkenli kalite kontrol grafiklerinin etkinliğini sorgular hale getirmektedir. Örneğin bu durumla ilgili olarak Hotelling $T^{2}$ kontrol grafiğini ele alındığında; Hotelling (1947) [25] tarafından önerilen klasik çok değişkenli $T^{2}$ kontrol grafikleri ile Montgomery (2009)'nin [39] belirttiği üzere süreç ortalamasının takibi için birbiriyle ilişkili on ve daha az sayıda değişken takip edilebilmektedir. Dolayısıyla değişken sayısı arttığında, problem kaynaklarını teşhis etmede klasik çok değişkenli kontrol grafiklerinin performansı düşmektedir. $\mathrm{Bu}$ durumda çok değişkenli $E W M A$ ve CUSUM kontrol grafikleri gibi oldukça etkili yöntemler olmasına rağmen, yükselen değişken sayısı yine de bu kontrol grafiklerinin süreci izleme ve kontrol diş1 sinyalleri tespit performansının düşmesine neden olmaktadır [40].

Literatürde, değişken sayısının fazla olması durumunda temel bileşenler analizi, faktör analizi ve gizil kök gibi yöntemlerin kullanılarak bu sayının azaltılması önerilmektedir. Çok değişkenli kontrol grafiklerinde kullanılan faktör analizi yaklaşımı ile ilgili gerekli detaylar Apley ve Shi (1998) [41] ve Lee ve Apley (2004) [42] tarafından yapılan çalışmalarda, temel bileşenler analizi ile ilgili detaylar ise Yang, He ve Xie (1994) [43] ve Ceglarek, Shi ve Wu (1994) [44] tarafindan yapılan çalışmalarda bulunmaktadır. Ayrıca, değişken sayısı fazla olduğunda kontrol altına alınabilen ve bilinen nedenlere (anticipated assignable causes) bağlı kontrol grafiklerinin dizayn edilmesi de önem arz etmektedir.

İstatistiksel açıdan ortalama sapmalarını saptama gücü çok yüksek olan çok değişkenli kontrol grafiklerinin yorumlanması da zordur. Çünkü $\mathrm{T}^{2}$ istatistiği pratikte bir anlam taşımamaktadır. Son yıllarda $\mathrm{T}^{2}$ sinyallerini doğru yorumlayarak hata teşhisini kolaylaştırmak için birçok yöntem geliştirilmiş [45-47] olup bu yöntemlerin bir kısmı $\mathrm{T}^{2}$ grafiklerindeki sinyallerden hangi değişkenlerin sorumlu olduğunu saptamayı amaçlamaktadır [48-52]. Bu yöntemlerde sinyale etkisi en çok olan değişken ya da değişken grubunun belirlenmesiyle hata kaynağının doğrudan saptanacağı varsayılmaktadır.

Hata kaynaklarının belli değişkenleri doğrudan etkileyeceği varsayımı her zaman doğru olmamakta; belli değişkenler süreçteki hata kaynaklarının sadece bir kısmının etkilerini açıklayabilmektedir. $\mathrm{Bu}$ varsayımın geçerli olmadığ durumlarda, süreçteki hata kaynaklarının çok değişkenli gözlemlerde ne tür izler bırakacağı süreç uzmanlığına dayanarak belirlenerek bu izlerin saptanmasına yönelik yöntemler geliştirilmiştir. Bu izler, değişken ortalamalarının belli yönlerde sapması şeklinde $[28,35,52-54]$ ya da $T^{2}$ 
sinyallerinin kontrol grafiklerinde meydana getirdiği Şekil 1'de gösterilen izlere benzer örüntüler şeklinde [54] olabilmektedir.
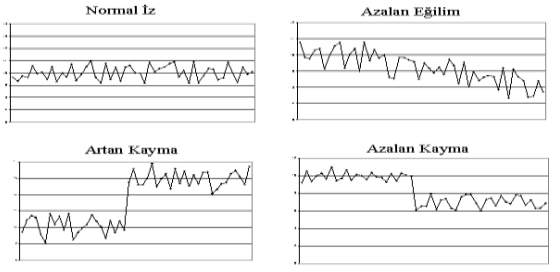

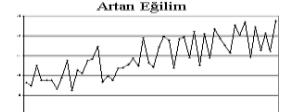

Şekil 1. Çok Değişkenli Kontrol Grafiklerinde Oluşan Tipik Örüntü Örnekleri

Kaynak: Orçanlı K., Oktay E. ve Birgören B. (2015). "Çok Değişkenli Kontrol Kartları Örüntü Tanıma Literatüründe Bir Araştırma", Social Sciences Research Journal, 4(2), 2342 [55]

Genellikle bu çalışmalar zaman boyunca değil, sadece bir parçadan alınan gözlemlerde oluşan izler üzerine yoğunlaşmışıtır. Bu kapsamda bir parça üzerinde aynı kalite karakteristiğinin çoklu ölçümleri alınıp bir kalite vektörü oluşturulmuş birçok örnekleri bulunmaktadır. Bu parçanın göstergesi olarak bu ölçümlerin birleştirilmesi sonucu kalite vektörü oluşturulur. Can ve Zhou (1993) [56] ve Avis ve Classen (1995) [57] tarafından yapılan çalışmalar bu kapsamda örnek olarak verilebilir.

Üretilmiş bir parçanın yüzeyindeki hata örüntüleri ile süreç hataları arasında ilişki kurma, kalite vektörünü temsil ederek parçaların üzerinde gözlemlenen hata örüntülerini teşhis etmek için bir yol sağlar. Süreçteki değişkenliğin veya yanlılı̆̆ının her potansiyel nedeni için bir hata izini tanımlamanın mümkün olduğu kabul edilmektedir. $\mathrm{Bu}$ bilgiler süreç bilgisinden, süreç hatalarının derin bir şekilde tanitılan deney tasarımından ya da simetri/asimetri örüntülerden elde edilmektedir [28]. Bu kapsamda, Apley ve Lee (2003) [58], Apley ve Shi (2001) [59] ve Jin ve Zhou (2006) [60] geçmişte birikmiş verilerde örüntü izlerinin tanımlanması için bazı metotlar önermiştir. Ding, Gupta ve Apley (2004) [61], Huang ve Shi (2004) [62] ve Jin ve Zhou (2006) [60] ise gözlemlenen kalite vektörünün örneklem kovaryans matrisini kullanarak hata izlerini tanımlamak için çeşitli yöntemler geliştirmiştir. Bu konu üzerine yapılan araştırmalar, çok değişkenli verilerde oluşan bazı örüntülerle problem kaynakları arasında doğrudan bağlantılar olmasından hareket etmişlerdir. Bu amaçla çok değişkenli uzayda yönlerle ilişkili kontrol bölgeleri tanımlanması [63] ve $T^{2}$ sinyalinin Scheffe tipi aralıklarla çözümlenerek anlamlı sapma yönlerinin bulunması [52] gibi çeşitli geliştirilen yöntemler vardır ve bu yöntemlerden birisi de regresyonla kalite vektörünün yönler cinsinden çözümlenmesi olan Süreç Tabanlı Temel Gösterimler (STTG) yöntemidir [28, 35].

\subsection{Süreç Tabanlı Temel Gösterimler Yönteminin Temelleri}

STTG yöntemi, Barton ve Gonzalez(1996) [28] tarafindan geliştirilmiş istatistik tabanlı çok değişkenli bir süreç teşhis yöntemidir [52, 64-66]. Bu yöntem; çok değişkenli verilerde oluşan desenleri saptamak amacıyla geliştirilmiş olup çoklu doğrusal regresyona dayanmakta ve üretim süreçlerindeki özel nedenlerin kalite vektörü üzerinde oluşturduğu örüntülerle bağlantı kurarak ürün performansındaki değişkenliğin en muhtemel sebeplerini tanımlamaktadır.

STTG yönteminin temelinde pozisyon boyut diyagramları ve çok boyut çizelgeleri yatmaktadır. Pozisyon boyut diyagramları, parçaların teknik çizimlerini andıran şekiller üzerinde, gözlem alınan noktalardaki ölçümleri göstermektedir. Çok boyut çizelgeleri ise, birbiriyle ilişkili birden çok kalite değişkenini belli geometrik şekiller oluşturacak şekilde çizelgeleyerek hata kaynaklarının ürettiği izler kolayca gözlenebilmektedir. Ayrıca STTG yönteminde bir ürüne ait çok değişkenli kalite karakteristikleri vektörünün hedef değere göre sapmaların oluşturduğu örüntü, birbirine göre bağımsız hata kaynaklarının hedef değere göre oluşturduğu örüntülerin cebirsel toplamına eşit olduğu mantığına dayanmaktadır. Dolayısıyla her bir hata kaynağının oluşturduğu örüntünün standart bir temel vektörü bulunmaktadır.

\subsection{STTG Yöntemine Matematiksel Bakış}

STTG yöntemi, bir süreçte özel nedenlerin çok değişkenli kalite vektörü $x$ üzerinde bilinen örüntüler oluşturduğu durumlarda regresyon analizi gibi tekniklerle kalite vektöründe hangi özel nedenlerin etkili olduğunu ortaya koymayı amaçlamaktadır.

$x$, kalite vektörü üzerinde hata kaynaklarının oluşturduğu sapmalardan oluşan örüntü matrisini, $A$, hata matrisini, $a_{i}, A$ hata matrisinin $i$ 'nci sütunu $i$ 'nci özel nedenin oluşturduğu örüntüyü veya hata vektörünü, $k$, bir süreçte tespit edilen hata sayısını $i=1,2, \ldots . k$ ve $m$ ise değişken sayısını temsil etsin. Dolayısıyla $\mathrm{k}$ adet hata kaynağının oluşturduğu $A$ hata matrisi, $A=\left[a_{1}\left|a_{2}\right| \ldots \mid a_{k}\right]$ şeklinde ve her bir hata ise $a_{i}$ şeklinde gösterilir. Burada $\left\{\mathrm{a}_{1}, \mathrm{a}_{2}, \ldots, \mathrm{a}_{\mathrm{k}}\right\}$ 'e "süreç tabanl temel elemanlar" denir. Kalite vektörü üzerinde oluşan $x$ örüntü vektörünü bağımlı değişken ve $A$ hata matrisinin her bir elemanını veya süreç tabanlı temel elemanı bağımsız değişken olarak kabul edersek STTG yönteminde matematiksel modeller hata matrisindeki satır ve sütun sayısına bağlı olarak denklem (2) ve denklem (3) şeklinde kurulmaktadır.

$$
x=A z \text { veya } x=A z+\varepsilon, \varepsilon \sim\left(0, \sigma^{2}\right) \text { b. o. } d
$$

Denklem (2) ve Denklem (3)'teki $z$ 'ler hata kaynağının büyüklügünü temsil etmektedir ve STTG katsayıları olarak adlandırılır. Denklem (2)'deki parametreler basit lineer 
denklem çözümü ile ve Denklem (3), parametreler ise en küçük kareler yöntemi ile elde edilmektedir. Söz konusu iki model çözümlenerek z'ler yani STTG katsayıları elde edilmektedir.

Yukarıda açıklandığı üzere temel elemanları temsil etmek üzere eğer konuyu basit bir cebir işlemi olarak düşünecek olursak $x$ vektörünün her bir bileşeni birbirinden bağımsız temel elemanlar oluşturmaktadır. Bu durumda $x$ vektörü, bağımsız temel elemanların toplamından oluşur ve $x=a_{1} e_{1}+a_{2} e_{2}+a_{3} e_{3}+\ldots \ldots ., a_{k} e_{k}$ şeklinde olur. Burada temel elemanlar yani e'ler $(1,0,0, \ldots \ldots . ., 0), \quad(0,1,0, \ldots \ldots . ., 0)$, $(0,0,1, \ldots \ldots . ., 0), \ldots \ldots . .(0,0,0, \ldots \ldots \ldots, 1)$ şeklinde alabiliriz. Ancak temel elemanların bu şekilde alınması problemin çözümü için yeterli olmamaktadır. Çünkü temel elemanların bağımsızlığı sağlanmıştır ancak her temel vektör sadece bir kalite karakteristiğini temsil etmektedir. Bu temel elemanlar yerine çok değişkenli kalite vektörünü temel eleman olarak temsil eden temel elemanlara ihtiyaç duyulmaktadır. İşte bu durumda temel elemanları göstermek amaciyla Barton ve Gonzalez (1996) [28] tarafindan önerilen temel eleman hesaplama yönteminin değeri ortaya çıkmaktadır.

Hata matrisinin satır ve sütunları yani çok değişkenli kalite vektöründeki değişken sayısı ile hata sayısı eşit ise yukarıda belirtilen matematik modelden Denklem (2) kullanılır. Eğer hata kaynak vektörleri veya STTE'ler birbirinden bağımsız veya ortogonal ise söz konusu birinci matematiksel model $x=z_{1} a_{1}+z_{2} a_{2}+\ldots+z_{k} a_{k}$ şeklinde kurulmaktadır. Hata matrisinin satır sayısı sütun sayısından büyükse Denklem (3)'te yer alan matematiksel model kullanılır. Ancak genellikle kalite vektörü boyutu özel neden sayısından büyük olduğu için daha çok bu matematiksel modellerden Denklem (3)'te yer alan matematiksel model kullanılır. Literatürde hata terimi vektörü $\varepsilon$ için $\varepsilon_{\mathrm{i}} \sim N\left(0, \sigma^{2}\right)$ ve bağımsız, özdeş, dağılmış (b.ö.d.) varsayılmıştır. Denklem (3)'te yer alan matematiksel modelde $a_{i}$ 'ler bilinen özel nedenleri modellediğinden hata terimi genel nedenler ile süreç üzerinde az veya hiç etkisi olmayan ve bilinmeyen diğer özel nedenleri temsil eder [28].

Yukarıda sözel olarak açıklanan yöntem matematiksel olarak şu şekilde açıklanabilir. Bir üründeki çoklu ölçüm değerlerinin sürecin sonunda ulaşılması istenen hedef değerlerden sapmalarından oluşan çok değişkenli kalite vektörü $x$, STTE matrisi $A$ ve STTG katsayıları $z$ ile gösterilecek olursa, yöntemle ilgili Denklem (2) ile Denklem (3)'te yer alan iki adet matematiksel model önerilmektedir. Denklem (2)'de yer alan matematiksel model $x=A z$ ve denklem (3)'te yer alan matematiksel model ise $\mathrm{x}=\mathrm{Az}+\varepsilon$ dir. Burada $\varepsilon_{i} \sim N\left(0, \sigma^{2}\right)$ ve $(b . \ddot{o} . d \text {. })^{\prime}$ 'dir. STTE hata matrisindeki kalite değişken sayısı ile STTE sayısının eşit olup olmamasına göre STTG katsayılarının hesaplanmasında bazı farklı1ıklar bulunmaktadır. Kalite değişkeni sayısı temel eleman sayısına eşit (denklem (2)) ise STTG katsayıları yani $z^{\prime}$ ler basit lineer eşitlik yardımıyla yani $z=(A)^{-1} x$ çözümü ile bulunur. Eğer STTE hata matrisinin satır sayısı sütun sayısından büyükse (denklem (3)) bu durumda ise STTG katsayıları $z=\left(A^{\prime} A\right)^{-1} A^{\prime} x$ çözümü ile çözülmektedir. Fakat STTE hata matrisinin satır sayısı sütun sayısından küçük olması durumunda belirtilen çözüm yaklaşımları ile STTG katsayıları hesaplanamamaktadır [28].

STTG yöntemi literatüründe Denklem (2) ve Denklem (3)'te yer alan matematiksel modeller bulunmaktadır. m'yi kalite vektöründeki kalite değişken sayısı ve $k^{\prime} y ı$ hata kaynağı sayısı olarak kabul edersek; $m<k$ durumu yani kalite değişken sayısının hata kaynağı sayısından az olması durumunda literatürde çözüm yolu veya uygulamaya yönelik yapılmış bir çalışma bulunmamaktadır. $m<k$ durumunda kullanılabilecek yol olarak değişken seçimi kavramı ortaya çıkmaktadır [28].

Çok değişkenli regresyon çözümlemesinde, modeli oluşturan bağımsız değişkenlerden bazılarının modele katkısı önemsiz olabilir. Bu nedenle bağımlı değişkeni en uygun şekilde açıklayacak bağımsız değişkenlerin belirlenmesi ve önemsiz değişkenlerin modelden çıkarılması gerekir. Bu sürece "değişken seçimi" denir. Değişken seçimi için kullanılan çeşitli yöntemler bulunmaktadır. Bu yöntemlerden biri adımsal regresyon yöntemleridir.

Buraya kadar STTG yönteminin mantığı ve kullanılan matematiksel modeller anlatılmaya çalışılmıştır. Özet olarak ele alınması gerekirse STTG metodolojisinin uygulama adımları aşağıya çıkarılmıştır. STTG metodolojisinin grafiksel olarak anlatımı ise Şekil 5'te verilmiştir [66].

1. Aşama: Kesin süreç problemleri belirlenir. Her farklı süreç problemi, $a_{1}, a_{2}, \ldots \ldots a_{k}$ olarak adlandırılmaktadır. Her bir $a$ vektörü bir adet hata kaynağını temsil etmekte ve bunlar süreç tabanlı temel elemanları olmaktadır. Daha sonra STTG metodolojisine uygun olarak süreç tabanlı temel elemanları birleştirilerek hata kaynağı matrisi $(A)$ yani temel elemanlar matrisi oluşturulmaktadır [66].

2. Aşama: m elemanlı $x$ kalite vektörünü oluşturmak için tek bir ürün için benzer ölçüm seti bulunmaktadır.

3. Aşama: 2'nci adımda elde edilen $x$ kalite vektörü bağımlı değişken ve 1 'inci adımda elde edilen süreç tabanlı temel elemanları (hata kaynakları) açıklayıcı (bağımsız) değişkenler olarak ele alınarak bunlara sıradan en küçük kareler yöntemi uygulanmaktadır. Bu sayede $x=A z+\varepsilon \varepsilon_{i} \sim$ $N\left(0, \sigma^{2}\right)$ ve $(b . \ddot{o} . d$.$) şeklindeki çoklu doğrusal regresyon$ yöntemi çözülür ve regresyon katsayıları elde edilmektedir. Burada elde edilen regresyon katsayıları STTG katsayıları olarak adlandırılmaktadır [66].

4. Aşama: STTG katsayıları tek veya çok değişkenli kontrol grafikleri ile izlenerek süreç hakkında karar verilmeye çalışılmaktadır. Eğer çok değişkenli kontrol grafiklerinde kontrol dışı sinyal tespit edilirse uygun ayrıştırma yöntemi ile hata kaynağı hangi STTG katsayısı veya katsayı gruplarından kaynaklandığı bulunmaya çalışılmaktadır. 


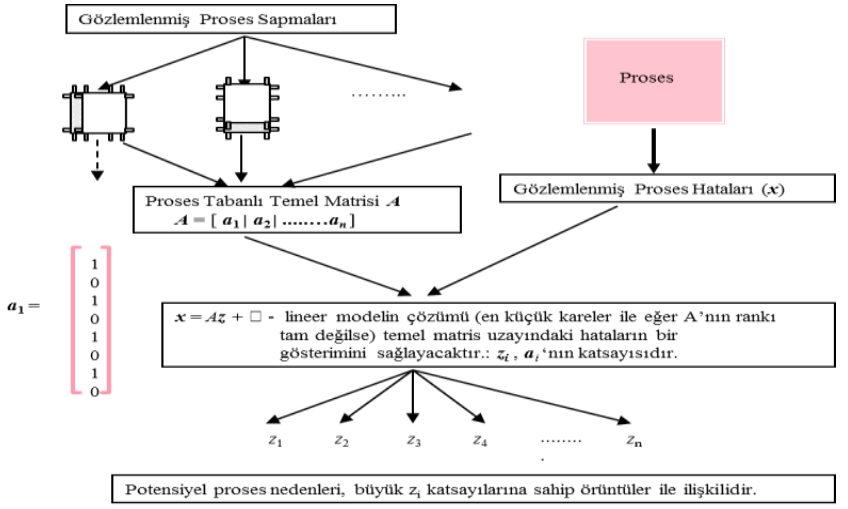

Şekil 5. STTG Yönteminin Özet Olarak Grafiksel Gösterimi

Kaynak: Padilla, V.O. (2005), Process oriented basis estimation in presence of non-orthogonal basis elements, (Master Thesis), University of Puerto Rico, Puerto Rico [66].

\subsection{STTG Yönteminin Yararları}

STTG yönteminin üretim süreçlerinde yapılan kalite kontrol uygulamaları kapsamında sağladığı yararlar Schmitt, Marcus ve Barton (2002) [67] tarafından yapılan çalışmada incelenmiş ve simülasyon ile temel bileşenler analizi ile STTG yöntemi karşılaştırılmıştır. Karşılaştırma sonucunda, STTG yönteminin temel bileşenler analizi yönteminden üstün olduğu ortaya konulmuştur. $\mathrm{Bu}$ karşılaştırmaya dayanarak Schmitt, Marcus ve Barton (2002) [67], STTG yönteminin yararlarını dört ana başlıkta toplamıştır. Bu kapsamda STTG yönteminin sağladığı yararlar aşağıya çıkarılmıştır.

- STTG yöntemi, çok sayıdaki birbiriyle ilişskili çok değişkenli verileri daha az boyuta indiren ve onları anlamlı bir hale sokan bir yöntemdir. Bu sayede süreçte meydana gelen kontrol dişı sinyali yorumlayacak hata teşhisi süreç uzmanları veya mühendisler açısından daha basit hale gelmektedir [28, 67, 63].

- Bir süreçte tek ve çok değişkenli kontrol grafikleri ile sürecin davranışı veya değişkenlik durumu izlenebilmektedir. Ancak, süreçte kontrol dişı bir durum oluştuğunda hata kaynaklarının tespiti için başka analitik yöntemler gerekmektedir. Ayrıca, çok değiş̧kenli kontrol grafikleri ile izlenen değişken sayısı onun üzerine çıktığında kontrol grafiklerinin etkinliği azalmaktadır [26]. STTG yöntemi, belirtilen bu iki duruma bir çözüm olarak kullanılabilmektedir.

- Barton ve Barreto (1999)’ya [68] göre STTG yönteminde, bir sürecin davranışını anlamak ve izlemek için diğer istatistiksel kalite kontrolü yöntemlerine göre daha az çaba harcanmaktadir.

- Apley ve Shi (2001)'e [59] göre STTG yönteminde, kontrol dışı sinyalin arkasında yatan hata daha kolay teşhis edilebilmektedir.
- STTG yönteminde bir süreçte meydana gelen kontrol dışı sinyali yönetme ve kontrol dışı teşhis ile ilgili maliyetler diğer yöntemlere göre daha düşüktür. Çünkü süreçte meydana gelen hata kaynakları önceden belirlendiğinden dolayı gayret ve çabalar önceden belirlenen hata kaynaklarına yönelmektedir. Dolayısıyla bütün hata kaynakları ile ilgilenme yerine sadece belirlenen hata kaynakları ile ilgilenildiğinden maliyet düşmektedir.

\subsection{STTG Yönteminin Sınırlıkları}

Klasik tek değişkenli süreç kontrol teknikleri, STTG metodolojisinde kullanılmaktadır. Tek değişkenli kontrol grafiklerinde, süreç değişkenlerini izlemek yerine en küçük kareler yöntemi sonucunda elde edilen STTG katsayıları izlenmektedir. Ancak STTG katsayılarının çok değişkenli kontrol grafikleri ile ilgili prosedürler uygulanacak olması durumunda beş önemli problem bulunmaktadır [63].

Birinci problem, STTG katsayılarının çok değişkenli normal dağılması varsayımını sağlayıp sağlamadığı ile ilgili problemdir. Çok değişkenli kontrol grafiklerinde izlenecek olan değişkenlerin çok değişkenli normal dağılması varsayımını sağlaması gerekir. Burada STTG katsayıları birlikte çok değişkenli normal dağılması varsayımını sağlaması konusunda bir garanti yoktur. Bu nedenle STTG katsayılarını çok değişkenli kontrol grafikleri ile izlemek için parametrik olmayan yöntemler önerilmiştir [63].

İkinci problem çok değişkenli kontrol grafikleri ile izlenen STTG katsayılarıyla ilgili yorumlama problemidir. Her ne kadar normal olarak geçmişten günümüze kontrol diş1 sinyalin yorumlanmasıyla ilgili ve bu bölümün ikinci kısmında anlatılan bazı yöntemler olsa da kesin bir çözüm elde edilememektedir. Barton ve Barreto (1996) [28] tarafından yapılan çalışmada, STTG katsayıları tek değişkenli kontrol grafikleri ile izlenebileceği gösterilmiştir. Ayrıca bu katsayıların çok değişkenli kontrol grafikleri ile de izlenilebileceği belirtilmiştir. Ancak, Birgören (1998) [63], genel bir eksiklik olarak bu katsayıların çok değişkenli kontrol grafikleri ile de izlenilebileceği ile ilgili tam olarak açık olmadığını belirtmektedir.

Üçüncü problem, ortaya konan hata vektörleri yani temel elemanlar arasındaki çoklu bağlantı sorunudur [35]. Çoklu bağlantı ortaya çıktığında, eğer çoklu doğrusallık tam ise STTG katsayıları belirsiz olup bunların standart hataları sonsuzdur. Eğer çoklu doğrusallık tamdan az ise, STTG katsayıları belirlenebilmekle beraber katsayılara oranla büyük standart hatalar taşırlar. Bu da katsayıların büyük bir doğruluk veya kesinlikle tahmin edilememeleri anlamına gelir [25]. Barton ve Barreto (1996) [28], Espada-Colon ve Gonzalez-Barreto (1997) [35], Padilla (2005) [66] söz konusu problemin STTG metodolojisinde nasıl halledilebileceğini göstermiş ve yöntemleri açıklamıştır.

Dördüncü problem, yapılan bu çalışmada tespit edilen durumdur. Regresyon varsayımları incelendiğinde; varsayımlardan bir tanesi gözlen sayısının değişken sayısından devamlı olarak büyük olması varsayımıdır. 
Yapılan vaka çalışmasında bu durum ile karşı karşıya kalınmıştır. Bu durumda istatistikte değişken azaltma veya değişken seçim teknikleri kullanılabilmektedir (Değişken azaltma yöntemleri ve adımsal (stepwise) regresyon analiz yöntemi).

Beşinci problem, yine bu çalışmaya paralel olarak Orçanlı, Birgören ve Oktay (2017) [55] tarafindan yazılan bir makalede gözlem sayısının değişken sayısından fazla olması durumunda kullanılabilecek denklem (3)'te yer alan modeldeki hata teriminim her zaman olmama durumudur. Dolayısıyla önerilen model elektronik sanayi için uygun olabilir ancak elektronik sanayisi dışındaki diğer endüstri alanında uygun olmama durumu ile karşı karşıya kalınabilmektedir.

\subsection{Adım: Değişkenlerin ve Parametrelerin Tanımı}

Aşağıdaki tanımlar üretilecek MS58 cinsi pirinç türü içindir. Pirinç türü değiştiğinde katsayı değerleri de değişmektedir. :Element türü, :Hurda türü,

$\boldsymbol{k} \quad$ :Kontrol grafikleri faz aşaması,

$\boldsymbol{t} \quad$ :Numune sayısı veya ölçüm vektörü sayısı,

$\boldsymbol{W}_{t, i x \mathbf{1}}$ :Spektral analiz sonunda elde edilen t'inci ölçüm vektörü

$\boldsymbol{W}_{i t} \quad$ :Spektral analiz sonunda elde edilen t'inci ölçüm vektörünün içindeki $i$ 'inci elementin yüzdesi

$\boldsymbol{W}_{\text {kit }}$ :Spektral analiz sonunda elde edilen k'ınc1 fazdaki t'inci ölçüm vektörünün içindeki $i$ 'inci elementin yüzdesi

$\boldsymbol{H}_{\boldsymbol{j}} \quad$ :j'inci hurda

$\boldsymbol{H}_{\boldsymbol{i} \boldsymbol{j}} \quad$ :j'inci hurdanın $i$ 'inci elementinin yüzdesi

$\boldsymbol{x}_{\boldsymbol{t}, \boldsymbol{i x} \boldsymbol{1}}$ :Spektral analiz sonunda elde edilen t'inci ölçüm vektörü ile hedef MS58 cins pirinç element yüzdelerini içeren vektör arasındaki hata vektörü yani analize konu olan kalite vektörü

$\boldsymbol{x}_{\text {kit }}$ :Analize konu olan $k^{\prime}$ 'ncı fazdaki t'inci kalite vektörünün içindeki $i$ 'inci elementin yüzdesi

$\boldsymbol{A}_{\boldsymbol{i x t}} \quad$ :m sayıda kalite değişkenli ve t hata sayılı süreç tabanli temel elemanlar matrisi

$\boldsymbol{a}_{\boldsymbol{j}} \quad$ :j'inci süreç tabanlı temel elemanlar vektörü

$\boldsymbol{a}_{\boldsymbol{i j}} \quad$ :j'inci süreç tabanlı temel elemanlar vektörünün $i$ 'inci elementin yüzdesi

$\boldsymbol{z}_{\boldsymbol{k}} \quad k^{\prime}$ inci faz aşamasının $j$ 'inci süreç tabanlı temel gösterimleri katsayısı

$\boldsymbol{D}_{\boldsymbol{i x 1} \mathbf{1}}$ :Hedef MS58 cins pirinç element yüzdelerini içeren vektör

$\boldsymbol{D}_{\boldsymbol{i}} \quad$ :Hedef MS58 cins pirincin $i$ 'inci element yüzdesi

$\boldsymbol{M}_{\boldsymbol{D}} \quad:$ Hedef MS58 cins pirincin a $\mathrm{ğrl}_{1} \breve{g ̆}_{1}$

$\boldsymbol{m}_{\boldsymbol{j}}$ :Karışıma $\boldsymbol{j}$ 'inci hurdadan atılan fazla veya eksik atılan miktarın ağırlı̆̆

$\boldsymbol{\varepsilon} \quad$ :Hata terimi veya genel nedenler, $\varepsilon \sim N\left(0, \sigma^{2}\right)$

\subsection{Adım: Modelin Kurulması}

Literatür incelendiğinde, STTG yöntemi ile ilgili Barton ve Gonzalez (1996) [28] tarafından önerilen iki modelin ve Runger, Barton, Castillo ve Woodall (2007) [40] tarafından önerilen üç matematiksel modelin bulunduğu tespit edilmiştir. Matematiksel modeller incelendiğinde, Pirinç Fabrikası Müdürlüğündeki üretim sürecine, Barton ve Gonzalez (1996) [28] tarafindan Denklem (3)'te yer alan matematiksel modelin uyduğu söylenebilir.

$$
x=A z+\varepsilon, \quad \varepsilon \sim N\left(0, \sigma^{2}\right)
$$

Yukarıda yer alan matematiksel modelin çoklu regresyon modeli olduğu görülmektedir. Ancak çoklu regresyon modelinden fark1, bu modelin orijinden geçen bir model olmasıdır. Çünkü model bağımlı ve bağımsız değişkenlerin ortalamaya göre veya herhangi bir vektöre göre sapma değerlerine dayalı kurulması durumunda sabit katsayı hesaplanamamaktadır.

\subsection{Adım: Kalite Vektörü (x)’nün Oluşturulması}

Çalışmada kullanılacak kalite vektörü, eriyikten alınan numunelerin spektral analiz sonucunda elde edilen element yüzdelerinin oluşturduğu çok değişkenli gözlem vektörü $(W)$ ile DIN standartlarında ve döküm sonunda ulaşılmak istenen hedef değer vektörü arasındaki fark olan hata vektöründen oluşmaktadır. Burada döküm sonunda ulaşılmak istenen hedef değer vektörü $D$ ile simgelenecek olunursa, hedef değer vektörü $D_{i x 1}$ olarak gösterilebilir. Burada $i$, bu vektörün içindeki elementlerin sayısını simgelemektedir. Çalışmada yedi adet element olduğundan $i$ yedi değerini alır. Dolayisiyla bu vektör, yani $D_{7 \times 1}=\left(D_{1}, D_{2}, D_{3}, D_{4}, D_{5}, D_{6}\right.$, $D_{7}$ ) şeklinde gösterilir. Burada hedef değer vektörü;

$$
\left.D_{7 \times 1}=\begin{array}{c}
58 \\
3 \\
0.25 \\
0.2 \\
0.05 \\
0.25 \\
0.01
\end{array}\right\rfloor
$$

olur. Bu vektörde yer alan değerler Tablo 1 'de gösterilen element değerlerinin alt ve üst değerlerinin ortalamasıdır. Örneğin, 1'inci element olan $\mathrm{Cu}$ elementinin alt sınırı \%57, üst sınırı ise \%59'dur. Dolayısıyla alt ve üst sınırların değerleri ortalamasi; $(\% 59+\% 57) / 2=\% 58$ olarak hesaplanir.

Eğer her bir $W$ vektöründen $D_{i x 1}$ vektörünü çıkartacak olursak; ikinci durumda kullanılacak çok değişkenli gözlem fark vektörleri (Formül 1'deki ve Formül 2'deki $x$ 'ler) elde edilir. Dolayısıyla kalite vektörü aşağıda yer alan formülasyon ile genelleştirilebilir. 


$$
\begin{aligned}
& W_{\text {kit }}-58.0 \\
& W_{\text {kit }}-3.00 \quad k=1,2 \\
& W_{\text {kit }}-0.25 \\
& x_{\text {kit }}=W_{\text {kit }}-0.20 \quad \operatorname{Faz} I(k=1): i: 1,2, \ldots \ldots .7 \text { ve } t=1,2, \ldots \ldots . .50 \\
& W_{\text {kit }}-0.05 \\
& \left\lfloor\begin{array}{l}
W_{k i t}-0.25 \\
W_{k i t}-0.01
\end{array}\right\rfloor \\
& \operatorname{Faz} \text { II }(k=2): i: 1,2, \ldots \ldots . .7 \text { ve } t=1,2, \ldots \ldots .334
\end{aligned}
$$

Ayrıca yukarıda yer alan formülasyonda $k$ ve $t$ simgeleri yer almaktadır. Formülasyonda $k$ ve $t$ simgeleri faz aşamalarını ve örneklemlerdeki gözlemleri temsil etmektedir. İstatistiksel kontrol grafiklerinde süreç standart sapması ve sürecin ortalaması bilinmediğinde söz konusu değerler süreçten alınan örneklemden hesaplanır. Bu durumda sürece ait standart sapma ve ortalama değerleri bulabilmek için kontrol grafikleri iki aşamada kurulur ve her bir aşama faz olarak isimlendirilir. Kontrol grafiklerinin $\mathrm{Faz} I$ ve $\mathrm{Faz}$ II safhası olarak iki aşamada kurulmasından dolayı, $\boldsymbol{k}$; faz adımlarını, $t$; Faz I ve Faz II aşamalarında izlenen örneklem hacimlerini ve $\boldsymbol{i}$ : kalite karakteristiklerini yani element sayısını temsil etmektedir. Bu çalışmada örneklem hacimleri 50 ölçüm ve 334 ölçüm olmasından dolayı t'ye Faz I aşamasında 50 değeri ve $F a z$ II aşamasında ise 334 değeri atanmıştır.

\subsection{Adım: Süreç Tabanlı Temel Elemanları (A)’nın Üretilmesi}

Özel (2005) [1] tarafindan yapılan çalıșmada, kalite karakteristiği olarak belirlenen eriyik haldeki pirinç alaşımı içindeki element oranları tek ve çok değişkenli kontrol grafikleri ile incelenmiş ve kontrol dişı sinyal tespit edildiğinde yorumlanması esnasında hata kaynağı MYT ayrıştırma metodu ile değişkenlerde yani element oranlarında aranmıştır. Ancak bu element oranlarında hata kaynağının aranması süreç uzmanlarına sınırlı bilgi sunar. Bunun üzerine söz konusu problem ile ilgili olarak daha sonra sebep-etki diyagramı oluşturulmuş ve bu problemin hata kaynaklarını bulmak amacıyla süreç ve kalite uzmanlarından yardım alınmıştır. İnceleme sonunda istenilen özelliklerde pirinç alaşımının üretilmesine etki eden bilinen hata kaynağı olarak birçok neden ortaya konmuş, ancak bilinen hata kaynağı olarak "üretim sürecinin başında saf ve hurda malzemelerin harmanlanmass sonucunda oluşturulan şarjlarda hurda malzemelerin kantardan, malzemenin durumundan veya personelden kaynaklanan istenen oranda konulamaması" yani "şarj içine hurda cinslerinin fazla veya az konulması" olarak belirlenmiştir. Dolayısıyla hata kaynaklarının yani süreç tabanlı temel elemanlar matrisinin oluşturulmasında temel elemanların hurda cinsleri tarafından temsil edilmesi gerektiğine karar verilmiştir. STTG yöntemindeki matematiksel model incelendiğinde eriyik haldeki pirinç alaşımı elementlerin yüzde oranlarının kalite vektörü olan DIN 17660 standartları göre oluşturduğu sapmaların oluşturduğu örüntü, hata kaynağ1 olarak kabul edilen hurdaların elementlerin yüzde değerlerinin yine kalite vektörü olan DIN 17660 standartları göre oluşturduğu sapmaların oluşturduğu örüntülerin toplamından oluşmaktadır.
Söz konusu modeli Pirinç Fabrikası Müdürlüğü üretim sürecinde uygulayabilmek amacıyla fabrikanın son sekiz

\begin{tabular}{|c|c|}
\hline Hurda Numarası & Hurda İsmi \\
\hline \multicolumn{2}{|c|}{ Pirinç Fabrikası Müdürlüğü dâhili } \\
\hline 1.Hurda & MS 58 (Ara iş) \\
\hline 2.Hurda & Kovanlık-fişeklik MS-70 (Ara iş) \\
\hline 3.Hurda & MS 90 Tombak Paket (Yüksük) \\
\hline 4.Hurda & Soyma $\mathrm{Cu}$ \\
\hline 5.Hurda & Kablo Bakırı (Granül Bakır) \\
\hline 6.Hurda & Hurda Radyatör \\
\hline 7.Hurda & Hurda Elektrolit Zn (E-Zn) \\
\hline 8.Hurda & Reganya Toprak \\
\hline 9.Hurda & Reganya Takoz \\
\hline 10.Hurda & Elektrolit Külçe Kurşun (E-Pb) \\
\hline 11.Hurda & Katot Bakır \\
\hline \multicolumn{2}{|c|}{ Pirinç Fabrikası Müdürlüğü harici } \\
\hline 12.Hurda & Demirli Tombak (Yüksük 90) \\
\hline 13.Hurda & Pirinç 70 (G.Ankara Talaşı) \\
\hline 14.Hurda & Boş kovan 70 (Fesih Hurda Kovan) \\
\hline 15.Hurda & Hurda Kapçık 70 (Fesih Hurda Kapçık) \\
\hline 16.Hurda & Elektrolit Külçe Zn (E-Zn) \\
\hline 17.Hurda & Harici Pirinç ve Bronz Talaşı \\
\hline 18.Hurda & Harici Pirinç ve Bronz Hurdası \\
\hline 19.Hurda & Harici Hurda Bakır \\
\hline 20.Hurda & Kurşunlu Kapçık Müftüoğlu \\
\hline 21.Hurda & Gemi Hurdası \\
\hline 22.Hurda & Çelik Jant (araç) \\
\hline 23.Hurda & Yüksük Ara İşi \\
\hline 24.Hurda & Kovan Pulu Ara İşi \\
\hline 25.Hurda & Boş Kovan 90 \\
\hline
\end{tabular}
sene üretim sürecinin kayıtları incelenmiştir. Pirinç Fabrikası Müdürlüğünde son sekiz sene içinde pirinç alaşımının üretiminde kullanılan 25 adet hurda cinsi tespit edilmiş olup, bu hurdaların isimleri Tablo 2'de sunulmuştur.

Tablo 2.Pirinç Fabrikası Müdürlüğünde Kullanılan Hurda Cinsleri

Ancak, pirinç alaşımı üretmek için kullanılan hurda cinsleri Tablo 2'de yer alan 25 adet hurda cinsi ile sınırlı değildir. Yani pirinç alaşımı içinde bulunan ve ana maddelerden olan $\mathrm{Pb}$ ve $\mathrm{Zn}$ elementlerinin yoğun olarak bulunduğu bütün hurda cinsleri kullanılmaktadır. Dolayısıyla pirinç alaşımı için kullanılan hurda cinslerinin sayısı Tablo 2'de yer alan 25 adet hurda cinsi sayısının üzerine çıkmaktadır. Ancak, bu çalışmada veriler 01 Ocak 2015-31 Mart 2015 döneminde toplanmıştır. $\mathrm{Bu}$ zaman diliminde üretilen pirinç alaşımları için 18 adet hurda cinsi kullanıldığ 1 için, çalışma 18 hurda cinsi ile sınırlandırılmıştır. Bu çalışmada kullanılan hurda cinsleri Tablo 3 'te verilmiştir.

Tablo 3.Pirinç Fabrikası Müdürlüğünde Son Sekiz Y1l İçinde Kullanılan Hurda Cinsleri

\begin{tabular}{|c|l|}
\hline \multicolumn{1}{|c|}{ Hurda Numarası } & \multicolumn{1}{|c|}{ Hurda İsmi } \\
\hline Pirinç Fabrikası Müdürlüğü dâhili \\
\hline 1.Hurda & MS 58 (Ara iş) \\
\hline 2.Hurda & Kovanlık-fişeklik MS-70 (Ara iş) \\
\hline 3.Hurda & MS 90 Tombak Paket (Yüksük) \\
\hline 4.Hurda & Soyma Cu \\
\hline 5.Hurda & Kablo Bakırı (Granül Bakır) \\
\hline 6.Hurda & Hurda Radyatör \\
\hline 7.Hurda & Hurda Elektrolit Zn (E-Zn) \\
\hline 8.Hurda & Reganya Toprak \\
\hline 9.Hurda & Reganya Takoz \\
\hline 10.Hurda & Elektrolit Külçe Kurşun (E-Pb) \\
\hline
\end{tabular}




\begin{tabular}{|l|l|}
\hline \multicolumn{2}{|l|}{ Pirinç Fabrikası Müdürlüğü harici } \\
\hline 11.Hurda & Pirinç 70 (G.Ankara Talaşı) \\
\hline 12.Hurda & Boş kovan 70 (Fesih Hurda Kovan) \\
\hline 13.Hurda & Hurda Kapçı 70 (Fesih Hurda Kapçı) \\
\hline 14.Hurda & Elektrolit Külçe Zn (E-Zn) \\
\hline 15.Hurda & Harici Pirinç ve Bronz Talaş1 \\
\hline 16.Hurda & Harici Pirinç ve Bronz Hurdası \\
\hline 17.Hurda & Harici Hurda Bakır \\
\hline 18.Hurda & Kurşunlu Kapçık Müftüoğlu \\
\hline
\end{tabular}

STTG yöntemindeki matematiksel model ele alındığında hata kaynağı veya bağımsız değişken sayısı on sekiz ve her bir hata kaynağındaki veya bağımsız değişkendeki çok değişkenli kalite vektöründeki kalite karakteristiği sayısı veya gözlem sayısı ise yedidir.

STTG yöntemi ile ilgili literatür araştırması incelendiğinde; iki çeşit matematiksel model (Formül-1 ve Formül-2) önerildiği tespit edilmiștir. Birinci matematiksel modeldeki (Formül-1) hata matrisi, hata kaynağ 1 ile kalite karakteristiğinin eşitliği varsayımı üzerine ve ikinci matematiksel model (Formül-2) ise kalite karakteristiği sayısının hata sayısından fazla olması varsayımı üzerine oluşturulduğu görülmüştür. $\mathrm{Bu}$ çalışmada yapılan uygulamada ise kalite karakteristiği sayısı hata kaynağı sayısından küçüktür. Dolayısıyla söz konusu her iki modelin, bu çalışmada kullanılamaması durumu ile karşılaşılmışıır. Karşılaşılan bu durumun regresyon analizi kullanılarak çözülebilir. Regresyon analizinde gözlem sayısı parametre sayısından az ise gözlem sayısının artııılması veya değişken sayısının azaltılması diğer bir değişle modele anlamlı değişkenlerin seçilmesi önerilmektedir. Anlamlı değişkenlerin seçilmesi için önerilen yöntemler sırasıyla bağımsız değişkenleri birleştirme yöntemi, tüm muhtemel alt kümeler yöntemi, adımsal yöntemler ve genelleştirilmiş ters matris olarak dört gruba ayrılmaktadır.

Bağımsız değişkenleri birleştirme yönteminde, aynı veya aralarında tam pozitif korelasyona sahip gözlem değerleri sadece bir değişken tarafindan temsil edilir. Dolayısıyla örneğin bu durumda beş bağımsız değişken varsa bu beș bağımsız değişken sadece bir bağımsız değişken ile temsil edilir ve toplam bağımsız değişken sayısında dört adet bağımsız değiş̧ken eksilmiş olur.

Tüm muhtemel alt kümeler yönteminde, araştırmacının bir veya daha fazla aday bağımsız değişkeni içeren tüm regresyon denklemlerinin oluşturulması gerekir. $\mathrm{Bu}$ denklemler en uygun ölçütlere (çoklu belirtme katsayısı, düzeltilmiş çoklu belirtme katsayısı, artık kareler ortalaması, Mallow'un $C_{p}$ istatistiği, akaike bilgi ölçütü, bayesçi benzerler) göre değerlendirilir ve en iyi regresyon modeli seçilir. Tüm muhtemel regresyonlar hesaplama açısından yüklü olabileceğinden yalnızca az sayıdaki regresyon modellerini değerlendirmek amacıyla her adımda bağımsız değişkenleri ekleyerek ya da çıkartarak gerçekleştirilen farklı yöntemler bulunmaktadır. $\mathrm{Bu}$ yöntemler adımsal yöntemler olarak adlandırılmaktadır. $\mathrm{Bu}$ yöntemler genellikle üç kategoride sınıflandırılmaktadır. Bu yöntemler sırasıyla ileriye doğru seçim, geriye doğru çıkarma ve adımsal seçimdir [69]. Yukarıda açıklanan değişken indirme yöntemlerinin bu çalışmada hata kaynağı veya kurulan modelde bağımsız değişken olarak seçilen hurdaların özellikleri ile ilgili olarak yapılan değişsen azaltma işlemleri müteakip maddelerde açıklanmıştır. Ancak bu kapsamda yapılan işlemlerle ilgili olarak hurdaların içindeki elementlerin oranları Orçanlı (2017) [70] tarafindan hazırlanan doktora tezinde yer almaktadır.

Hurda malzemelerin içindeki elementlerin yüzde oranlarına bakıldığında; 3.Hurda: MS 90 Tombak Paket (Yüksük), 4.Hurda: Soyma $\mathrm{Cu}$, 5.Hurda: Kablo $\mathrm{Cu}(\mathrm{Granül} \mathrm{Cu})$, 7.Hurda: Hurda Elektrolit Zn (E-Zn), 10.Hurda: Elektrolit Külçe Kurşun (E-Pb), 14.Hurda: Elektrolit Külçe Zn (E-Zn) ve 17.Hurda: Harici Hurda $\mathrm{Cu}$ cinslerinin saf malzeme (malzemeler her ne kadar hurda olsa da saf malzeme özelliği taşımakta olup emprüteler ihmal edilecek kadar az bulunmaktadır) olduğu görülmektedir. Dolayısıyla modelimize hata kaynağı olarak başlangıçta bulunan 18 hurda cinsinin içinden bu saf malzeme özelliği taşıyan hurda cinslerini çıkararak geri kalan 11 hurda cinsini almamız gerekmektedir.

Geri kalan hurda cinslerinin element oranlarını tekrar incelediğimizde, bazı elementlerin oranlarının aynı, bazılarının ise önemsiz sayılabilecek derecede farklı olduğu görülmektedir. Dolayısıyla içindeki element oranları yakın olan hurdalar da kendi arasında gruplamaya tabi tutulmuştur. Burada her grup bir adet hata kaynağını oluşturmaktadır. Sınıflandırmaya saf malzemeler dâhil edilmemiştir. Pirinç Fabrikası Müdürlüğ̈̈nün tanıtımı yapılırken hurda çeşitlerinin birçok kaynaktan geldiği ifade edilmiştir. Farklı kaynaklardan gelen hurda malzemelere çeşitli isimler verilmektedir. Hatta endüstrilerde ayn kullanım alanı olan malzemeler bile farklı adlandırılabilmektedir. Örnek vermek gerekirse, savunma sanayisinde mermi kovanları kullanılan silah cinsine göre farklı isimler almaktadır: $7.62 \mathrm{~mm}$ çapında G-3 piyade tüfeğinin mermisinin boş kovanı hafif silah boş kovanı diye isimlendirilirken, $12.7 \mathrm{~mm}$ çapında uçaksavar mermisinin boş kovanı ise ağır silah boş kovanı diye isimlendirilmektedir. Ancak söz konusu bu iki boş kovanın yapıldığı alaşımın cinsi aynıdır ve içindeki elementlerin yüzdeleri de aynı değerlere sahip olabilmektedir. Dolayısıyla bu çalışma kapsamında element oranları dikkate alınarak birbiriyle aynı hatta birbirine çok yakın özelliklerde hurdalar gruplandırılabilir. Bu kapsamda on bir çeşit hurda, element oranları dikkate alınarak altı grup altında sınıflandııılmıştır. $\mathrm{Bu}$ kapsamda yapılan gruplandırma Tablo 5'te ve yapilan gruplamanın element değerlerinin yüzde değerleri ise Tablo 6'da gösterilmiş̧tir. 
Tablo 5. Gruplama Sonrası Hurda Grupları

\begin{tabular}{|c|l|}
\hline Hurda Numarası & \multicolumn{1}{|c|}{ Hurda İsmi } \\
\hline 1.Hurda Grubu & 1.Hurda MS 58 (Ara iş) \\
\hline \multirow{5}{*}{ 2.Hurda Grubu } & 2.Hurda Kovanlık-fişeklik MS-70 (Ara iş) \\
\cline { 2 - 2 } & 11.Hurda Pirinç 70 (G.Ankara Talaş1) \\
\cline { 2 - 2 } & $\begin{array}{l}\text { 12.Hurda Boş kovan 70 (Fesih-Fesih Hurda } \\
\text { Kovan) }\end{array}$ \\
\cline { 2 - 2 } & $\begin{array}{l}\text { 13.Hurda Hurda Kapçık 70 (Fesih-Fesih } \\
\text { Hurda Kapçık) }\end{array}$ \\
\cline { 2 - 2 } & 18.Hurda Kurşunlu Kapçık Müftüoğlu \\
\hline 3.Hurda Grubu & 6.Hurda Hurda Radyatör \\
\hline 4.Hurda Grubu & 8.Hurda Reganya Toprak \\
\hline 5.Hurda Grubu & 9.Hurda Reganya Takoz \\
\hline \multirow{2}{*}{ 6.Hurda Grubu } & 15.Hurda Harici Piriçç ve Bronz Talaş1 \\
\cline { 2 - 2 } & 16.Hurda Harici Pirinç ve Bronz Hurdas1 \\
\hline \multirow{5}{*}{ Saf Hurda Grubu } & 3.Hurda MS 90 Tombak Paket (Yüksük) \\
\cline { 2 - 2 } & 4.Hurda Soyma Cu \\
\cline { 2 - 2 } & 5.Hurda Kablo Cu (Granül Cu) \\
\cline { 2 - 2 } & 7.Hurda Hurda Elektrolit Zn (E-Zn) \\
\cline { 2 - 2 } & 10.Hurda Elektrolit Külçe Kurşun (E-Pb) \\
\cline { 2 - 2 } & 14.Hurda Elektrolit Külçe Zn (E-Zn) \\
\cline { 2 - 2 } & 17.Hurda Harici Hurda Cu \\
\hline
\end{tabular}

Tablo 6. 6 Adet Hurda Grubunun Element Oranları

\begin{tabular}{|l|l|l|l|l|l|l|}
\hline Element & $\begin{array}{c}1 . \\
\text { HHK }\end{array}$ & $\begin{array}{c}2 . \\
\text { HHK }\end{array}$ & $\begin{array}{c}3 . \\
\text { HHK }\end{array}$ & $\begin{array}{c}4 . \\
\text { HHK }\end{array}$ & $\begin{array}{c}5 . \\
\text { HHK }\end{array}$ & $\begin{array}{c}6 . \\
\text { HHK }\end{array}$ \\
\hline $\mathrm{Cu}$ & $58 \%$ & $69.94 \%$ & $71 \%$ & $57.5 \%$ & $64 \%$ & $57.5 \%$ \\
\hline $\mathrm{Pb}$ & $2 \%$ & $0.035 \%$ & $3 \%$ & $2 \%$ & $2.5 \%$ & $4 \%$ \\
\hline $\mathrm{Fe}$ & $0.015 \%$ & $0.025 \%$ & $0.22 \%$ & $0.6 \%$ & $0.94 \%$ & $0.22 \%$ \\
\hline $\mathrm{Sn}$ & $0.015 \%$ & $0.025 \%$ & $1.22 \%$ & $0.25 \%$ & $1.22 \%$ & $1.22 \%$ \\
\hline $\mathrm{Al}$ & $0.025 \%$ & $0.005 \%$ & $0.025 \%$ & $0.1 \%$ & $0.125 \%$ & $0.1 \%$ \\
\hline $\mathrm{Ni}$ & $0.015 \%$ & $0.025 \%$ & $0.22 \%$ & $0.125 \%$ & $0.27 \%$ & $0.22 \%$ \\
\hline $\mathrm{Sb}$ & $0.01 \%$ & $0.0005 \%$ & $0.01 \%$ & $0.0013 \%$ & $0.03 \%$ & $0.0125 \%$ \\
\hline
\end{tabular}

Yapılan çalışmada STTG yönteminde ihtiyaç duyulan temel elemanlar temel cebirde olduğu gibi gösterilebilir. Yani, yukarıda gösterildiği üzere altı adet hata kaynağının temel elemanları $(1,0,0,0,0,0,0)$,

$(0,1,0,0,0,0,0)$,

$(0,0,0,0,0,0,1)$ şeklinde temsil edilebilir. $\mathrm{Bu}$ şekilde gösterilen temel elemanlar ortogonaldır. Ancak bu şekilde gösterimde hata kaynağının sadece 1 rakamı ile temsil edilen elementindeki sapma miktarı hesaba katılmış olur ve diğer elementlerdeki sapmalar hesaba katılmaz. Dolayısıyla bütün elementlerdeki sapmaları aynı anda ve elementlerin arasındaki ilişkileri dikkate alacak STTG yöntemindeki bakış açısıyla Pirinç Fabrikası Müdürlüğünün üretim sürecinde temel elemanların oluşturulması gerekmektedir.

\subsubsection{Hurda Malzemelerin Az veya Çok Atılmasının Modellenmesi}

Pirinç Fabrikası Müdürlüğü üretim sürecinde DIN 17660 standartlarında MS58 pirinç cinsinin element oranlarına yani ideal element yüzde oranlarına sahip $M_{D} \mathrm{~kg}$ bir pirinç alaşımının üretildiğini düşünelim. Bu durumda ideal element oranlarına sahip olan üretilmiş pirinç alaşımı şöyle gösterilir.

$$
M_{D} \times\left[\begin{array}{c}
D_{1} \\
\cdots \\
D_{i}
\end{array}\right]
$$

D, ideal ölçülerde üretilen ix1 boyutunda MS58 cinsi pirinç alaşım vektörünü ve $D_{i}$ ise ideal ölçülerde üretilmiş MS58 cinsi pirinç alaşımının i elementinin ağırlıkça yüzde değerini temsil etmektedir. $M_{D}$ ise üretim sonunda ideal ölçülerde üretilmiş MS58 cinsi pirinç alaşımının ağırlığıdır. Burada yedi elementin haricinde olan diğer elementlerin ağırlığı ve dolayısıyla yüzde oranı çok küçük olmasından dolayı dikkate alınmamıştır ve üretilen pirinç cinsinin içinde sadece yedi adet element olduğu farz edilmiştir. Dolayısıyla $\mathrm{D}_{\mathrm{i}}$ 'nin değeri (yüzde değeri), MS58 pirinç cinsinin içindeki i'inci elementin ağırlığını yani $m_{j}$ 'yi, $M_{D}$ olan toplam ağırlığa bölünerek bulunur.

Daha sonra ideal ölçülerde üretilmiş bir üründe j’inci cins hurda cinsinden $m_{j} \mathrm{~kg}$ kadar fazla atıldığını düşünelim. Burada hurda cinsleri $\mathrm{H}$ simgesi ile gösterilecektir. $\mathrm{H}_{\mathrm{j}}$ ise j'inci hurdayı $\mathrm{H}_{\mathrm{ij}}$ ise $\mathrm{j}$ 'inci hurdanın i'inci element yüzdesini göstermektedir. Eğer üretim sonunda elde edilen ideal ölçülerdeki $M_{D}$ kg kadar MS58 pirinç cinsine çeşitli genel sebeplerden dolayı $\mathrm{m}_{\mathrm{j}} \mathrm{kg}$ kadar $\mathrm{H}_{\mathrm{j}}$ hurdasından fazla atılma durumunda;

$$
M_{D} \operatorname{kg} \times\left[\begin{array}{c}
D_{1} \\
\ldots \\
D_{i}
\end{array}\right]+m_{j} \operatorname{kg} \times\left[\begin{array}{c}
H_{1 j} \\
. . \\
H_{i j}
\end{array}\right]
$$

elde edilir. $\mathrm{Bu}$ şekilde elde edilen yeni karışımın içindeki elementlerin kg cinsinden ağırlıkları şu şekilde bulunur.

$$
\left[\begin{array}{c}
\mathrm{M}_{\mathrm{D}} \mathrm{kgxD}_{1+} \mathrm{m}_{\mathrm{j}} \mathrm{xH} \mathrm{H}_{1 \mathrm{j}} \\
\ldots \\
\mathrm{M}_{\mathrm{D}} \operatorname{kgxD}_{\mathrm{i}+} \mathrm{m}_{\mathrm{j}} \mathrm{xH} \mathrm{H}_{\mathrm{ij}}
\end{array}\right]
$$

$\mathrm{Bu}$ yeni durumda yeni üretilen pirinç cinsinin ağırlığ yukarıda yer alan matristeki elementlerin toplamı kadardır ve aşağıda olduğu gibi gösterilir.

$$
\left[M_{D} \operatorname{kgx}\left(D_{1+} D_{2+\cdots+} D_{i}\right)+m_{j} x\left(H_{1 j}+\cdots+H_{i j}\right)\right]
$$

Yukarıda yer alan denklemde parantez içinde olan ideal pirinç alaşımının ve hurdaların içinde bulunan element yüzde değerleri olduğu için bu yüzde değerlerinin toplamı 1'e eşittir. Bu durumda üretim süreci sonunda elde edilen pirinç alaşımının toplam ağırlığı $\mathrm{kg}$ cinsinden $M_{D} \mathrm{~kg}+\mathrm{m}_{\mathrm{j}} \mathrm{kg}$ olmaktadir.

Üretim sonunda fazla atılan hurdayı da içine kaplayacak şekilde üretilen pirinç alaşımının yeni duruma göre yani yeni yüzdelik ölçüm değerleri aşağıda gösterilmiştir.

$$
\left[\begin{array}{c}
M_{D} \operatorname{kgxD}_{1+} m_{j} x_{1 j} \\
. . \\
M_{D} \operatorname{kgxD}_{i+} m_{j} x H_{i j}
\end{array}\right] /\left(M_{D} k g+m_{j} k g\right)
$$

$\mathrm{Bu}$ duruma göre her bir boyutun elementlerin olduğu yedi boyutlu bir düzlem düşünecek olursak, fazla atılan hurda cinsinin elementlerinin yüzde cinsinden oluşan yedi boyutlu vektörü aşağıdaki gibi hesaplanır.

$$
\left[\begin{array}{c}
\mathrm{M}_{\mathrm{D}} \mathrm{kgxD}_{1+} \mathrm{m}_{\mathrm{j}} \mathrm{xH}_{1 \mathrm{j}} \\
. . \\
\mathrm{M}_{\mathrm{D}} \operatorname{kgx}_{\mathrm{i}+} \mathrm{m}_{\mathrm{j}} \mathrm{xH}_{\mathrm{ij}}
\end{array}\right] /\left(\mathrm{M}_{\mathrm{D}} \mathrm{kg}+\mathrm{m}_{\mathrm{j}} \mathrm{kg}\right)=\left[\begin{array}{c}
\mathrm{D}_{1} \\
. . \\
\mathrm{D}_{\mathrm{i}}
\end{array}\right]+? ? ?
$$


Yukarıda yer alan eşitlikte soru işareti ile gösterilen yüzdeler vektör çözümü ile elde edilecektir. Yani iki boyutlu bir iki vektörün toplamının gösterimi ise aşağıdaki kartezyen koordinat sisteminde olduğu gibi hesaplanır.

$$
\begin{aligned}
& {\left[\begin{array}{c}
\mathrm{M}_{\mathrm{D}} \mathrm{kgxD}_{1+} \mathrm{m}_{\mathrm{j}} \mathrm{xH}_{1 \mathrm{j}} \\
\cdots \\
\mathrm{M}_{\mathrm{D}} \mathrm{kgxD}_{\mathrm{i}+} \mathrm{m}_{\mathrm{j}} \mathrm{xH}_{\mathrm{ij}}
\end{array}\right] /\left(\mathrm{M}_{\mathrm{D}} \mathrm{kg}+\mathrm{m}_{\mathrm{j}} \mathrm{kg}\right)=\left[\begin{array}{c}
\mathrm{D}_{1} \\
\ldots \\
\mathrm{D}_{\mathrm{i}}
\end{array}\right]} \\
& * \frac{\left(\mathrm{M}_{\mathrm{D}} \mathrm{kg}+\mathrm{m}_{\mathrm{j}} \mathrm{kg}\right)}{\left(\mathrm{M}_{\mathrm{D}} \mathrm{kg}+\mathrm{m}_{\mathrm{j}} \mathrm{kg}\right)}+? ? ? \\
& \frac{M_{D} k g x D_{i+} m_{j} x H_{i j}}{\left(M_{D} k g+m_{j} k g\right)}-D_{i} x \frac{\left(M_{D} k g+m_{j} k g\right)}{\left(M_{D} k g+m_{j} k g\right)}=? ? ? \\
& \frac{m_{j} x H_{i j}-D_{i} x m_{j} k g}{\left(M_{D} k g+m_{j} k g\right)}=? ? ? \\
& \frac{m_{j} x\left(H_{i j}-D_{i}\right)}{\left(M_{D} k g+m_{j} k g\right)}=? ? ? \\
& \frac{m_{j} k g}{\left(M_{D} k g+m_{j} k g\right)} \times\left[\begin{array}{c}
H_{1 j}-D_{1} \\
. . \\
H_{i j}-D_{i}
\end{array}\right]=? ? ? \\
& {\left[\begin{array}{c}
M_{D} \operatorname{kgx}_{1+} m_{j} x_{1 j} \\
\ldots \\
M_{D} \operatorname{kgxD}_{i+} m_{j} x_{i j}
\end{array}\right] /\left(M_{D} k g+m_{j} k g\right)=\left[\begin{array}{c}
D_{1} \\
. \\
D_{i}
\end{array}\right]} \\
& +\frac{m_{j} k g}{\left(M_{D} k g+m_{j} k g\right)} *\left[\begin{array}{c}
H_{1 j}-D_{1} \\
\cdots \\
H_{i j}-D_{i}
\end{array}\right]
\end{aligned}
$$

Eğer üretim sonunda elde edilen ideal ölçülerdeki $M_{D} \mathrm{~kg}$ kadar MS58 pirinç cinsine çeşitli genel sebeplerden dolayı $\mathrm{m}_{\mathrm{j}} \mathrm{kg}$ kadar $\mathrm{H}_{\mathrm{j}}$ hurdasından eksik atılma durumunda ise;

$$
M_{D} \operatorname{kg} x\left[\begin{array}{c}
D_{1} \\
. \\
D_{i}
\end{array}\right]-m_{j} \operatorname{kg} \times\left[\begin{array}{c}
H_{1 j} \\
. . \\
H_{i j}
\end{array}\right]
$$

elde edilir. $\mathrm{Bu}$ şekilde elde edilen yeni karışımın içindeki elementlerin $\mathrm{kg}$ cinsinden ağırlıkları şu şekilde bulunur.

$$
\left[\begin{array}{c}
\mathrm{M}_{\mathrm{D}} \mathrm{kgxD}_{1-} \mathrm{m}_{\mathrm{j}} \mathrm{xH}_{1 \mathrm{j}} \\
\ldots \\
\mathrm{M}_{\mathrm{D}} \operatorname{kgxD}_{\mathrm{i}-} \mathrm{m}_{\mathrm{j}} \mathrm{xH}_{\mathrm{ij}}
\end{array}\right]
$$

$\mathrm{Bu}$ yeni durumda yeni üretilen pirinç cinsinin ağırlığ yukarıda yer alan matristeki elementlerin farkları kadardır ve aşağıda olduğu gibi gösterilir.

$\left[M_{D} \operatorname{kg} \times\left(D_{i+} D_{2+\cdots+} D_{i}\right)-m_{j} \times\left(H_{1 j}+H_{2 j}+\cdots+H_{i j}\right)\right]$

Yukarıda yer alan denklemde parantez içinde olan ideal pirinç alaşımının ve hurdaların içinde bulunan element yüzde değerleri olduğu için bu yüzde değerlerinin toplamı 1'e eşittir. Bu durumda üretim süreci sonunda elde edilen pirinç alaşımının toplam ağırlığı $\mathrm{kg}$ cinsinden $\mathrm{M}_{\mathrm{D}} \mathrm{kg}-\mathrm{m}_{\mathrm{j}} \mathrm{kg}$ olmaktadir.

Üretim sonunda eksik atılan hurdayı da içine kaplayacak şekilde üretilen pirinç alaşımının yeni duruma göre yani yeni yüzdelik ölçüm değerleri aşağıda gösterilmiştir.

$$
\left[\begin{array}{c}
\mathrm{M}_{\mathrm{D}} \mathrm{kgxD}_{1-} \mathrm{m}_{\mathrm{j}} \mathrm{xH}_{1 \mathrm{j}} \\
\ldots \\
\mathrm{M}_{\mathrm{D}} \mathrm{kgxD}_{\mathrm{i}-} \mathrm{m}_{\mathrm{j}} \mathrm{xH} \mathrm{H}_{\mathrm{ij}}
\end{array}\right] /\left(\mathrm{M}_{\mathrm{D}} \mathrm{kg}-\mathrm{m}_{\mathrm{j}} \mathrm{kg}\right)
$$

$\mathrm{Bu}$ duruma göre her bir boyutun elementlerin olduğu yedi boyutlu bir düzlem düşünecek olursak eksik atılan hurda cinsinin elementlerinin yüzde cinsinden oluşan yedi boyutlu vektörü aşağıdaki gibi hesaplanır.

$$
\left[\begin{array}{c}
\mathrm{M}_{\mathrm{D}} \mathrm{kgxD}_{1-} \mathrm{m}_{\mathrm{j}} \mathrm{xH}_{1 \mathrm{j}} \\
. . \\
\mathrm{M}_{\mathrm{D}} \mathrm{kgxD}_{\mathrm{i}-} \mathrm{m}_{\mathrm{j}} \mathrm{xH}_{\mathrm{ij}}
\end{array}\right] /\left(\mathrm{M}_{\mathrm{D}} \mathrm{kg}-\mathrm{m}_{\mathrm{j}} \mathrm{kg}\right)=\left[\begin{array}{c}
\mathrm{D}_{1} \\
. . \\
\mathrm{D}_{\mathrm{i}}
\end{array}\right]+? ? ?
$$

Yukarıda yer alan eşitlikte soru işareti ile gösterilen yüzdeler

\begin{tabular}{|c|c|c|c|c|c|c|}
\hline & 1.STTE & 2.STTE & 3.STTE & 4.STTE & 5.STTE & 6.STTE \\
\hline $\mathrm{Cu}$ & 58-58 & $69.94-58$ & $71-58$ & $57.5-58$ & $64-58$ & 57.5-58 \\
\hline $\mathrm{Pb}$ & $2-3$ & $0.035-3$ & 3-3 & $2-3$ & $2.5-3$ & $4-3$ \\
\hline $\mathrm{Fe}$ & $0.015-0.25$ & $\begin{array}{c}0.025- \\
0.25\end{array}$ & $0.22-0.25$ & $0.6-0.25$ & $0.94-0.25$ & $0.22-0.25$ \\
\hline Sn & $0.015-0.2$ & $0.025-0.2$ & $1.22-0.2$ & $0.25-0.2$ & $1.22-0.2$ & $1.22-0.2$ \\
\hline $\mathrm{Al}$ & $0.025-0.05$ & $\begin{array}{c}0.005- \\
0.05\end{array}$ & $\begin{array}{c}0.025- \\
0.05\end{array}$ & $0.1-0.05$ & $\begin{array}{c}0.125- \\
0.05\end{array}$ & $0.1-0.05$ \\
\hline $\mathrm{Ni}$ & $0.015-0.25$ & $\begin{array}{c}0.025- \\
0.25\end{array}$ & $0.22-0.25$ & $\begin{array}{c}0.125- \\
0.25\end{array}$ & $0.27-0.25$ & $0.22-0.25$ \\
\hline $\mathrm{Sb}$ & $0.01-0.01$ & $\begin{array}{c}0.0005- \\
0.01 \\
\end{array}$ & $0.01-0.01$ & $\begin{array}{c}0.0013- \\
0.01 \\
\end{array}$ & $0.03-0.01$ & $\begin{array}{c}0.0125- \\
0.01 \\
\end{array}$ \\
\hline $\mathrm{Cu}$ & 0 & 11.94 & 13 & -0.5 & 6 & -0.5 \\
\hline $\mathrm{Pb}$ & -1 & -2.965 & 0 & -1 & -0.5 & 1 \\
\hline $\mathrm{Fe}$ & -0.235 & -0.225 & -0.03 & 0.35 & 0.69 & -0.03 \\
\hline Sn & -0.185 & -0.175 & 1.02 & 0.05 & 1.02 & 1.02 \\
\hline $\mathrm{Al}$ & -0.025 & -0.045 & -0.025 & 0.05 & 0.075 & 0.05 \\
\hline $\mathrm{Ni}$ & -0.235 & -0.225 & -0.03 & -0.125 & 0.02 & -0.03 \\
\hline $\mathrm{Sb}$ & 0 & -0.0095 & 0 & -0.0087 & 0.02 & 0.0025 \\
\hline
\end{tabular}
vektör çözümü ile elde edilecektir. Yani iki boyutlu bir iki vektörün toplamı düşünülecek olunursa gösterimi aşağıdaki kartezyen koordinat sisteminde olduğu gibi hesaplanır.

$$
\begin{aligned}
& {\left[\begin{array}{c}
M_{D} \operatorname{kgxD}_{1-} m_{j} x_{1 j} \\
\ldots \\
M_{D} \operatorname{kgxD}_{i-} m_{j} x_{i j}
\end{array}\right] /\left(M_{D} k g-m_{j} k g\right)=\left[\begin{array}{c}
D_{1} \\
\ldots \\
D_{i}
\end{array}\right]} \\
& \mathrm{x} \frac{\left(\mathrm{M}_{\mathrm{D}} \mathrm{kg}-\mathrm{m}_{\mathrm{j}} \mathrm{kg}\right)}{\left(\mathrm{M}_{\mathrm{D}} \mathrm{kg}-\mathrm{m}_{\mathrm{j}} \mathrm{kg}\right)}+? ? ? \\
& \frac{M_{D} k g x D_{i}-m_{j} \times H_{i j}}{\left(M_{D} k g-m_{j} k g\right)}-D_{i} x \frac{\left(M_{D} k g-m_{j} k g\right)}{\left(M_{D} k g-m_{j} k g\right)}=? ? ? \\
& \frac{-\mathrm{m}_{\mathrm{j}} \mathrm{xH}_{\mathrm{ij}}+\mathrm{D}_{\mathrm{i}} \mathrm{xm}_{\mathrm{j}} \mathrm{kg}}{\left(\mathrm{M}_{\mathrm{D}} \mathrm{kg}-\mathrm{m}_{\mathrm{j}} \mathrm{kg}\right)}=? ? ? \\
& \frac{-m_{j} x\left(H_{i j}-D_{i}\right)}{\left(M_{D} k g-m_{j} k g\right)}=? ? ? \\
& \frac{-m_{j} k g}{\left(M_{D} k g-m_{j} k g\right)} \times\left[\begin{array}{c}
H_{1 j}-D_{1} \\
\cdots \\
H_{i j}-D_{i}
\end{array}\right]=? ? ? \\
& {\left[\begin{array}{c}
M_{D} \operatorname{kgx}_{1-}-m_{j} x H_{1 j} \\
\ldots \\
M_{D} \operatorname{kgxD}_{i-} m_{j} x H_{i j}
\end{array}\right] /\left(M_{D} k g-m_{j} k g\right)=\left[\begin{array}{c}
D_{1} \\
. \\
D_{i}
\end{array}\right]+} \\
& \frac{-m_{j} k g}{\left(M_{D} k g-m_{j} k g\right)} \times\left[\begin{array}{c}
H_{1 j}-D_{1} \\
\cdots \\
H_{i j}-D_{i}
\end{array}\right] \text { Temel eleman }
\end{aligned}
$$

Yukarıda pirinç üretim sürecinde temel elemanların bulunması ile ilgili genelleştirilmiş bir formülasyon ortaya konulmaya çalışılmıştır. Konuyla ilgili olarak altı hata kaynağının temel elemanlarının oluşturulması Tablo 7'de gösterilmiştir.

Tablo 7. Gruplama Sonrası Oluşturulan Altı Adet Gruba Ait Temel Elemanlarının Hesaplanması 
STTG yönteminden çalışmamızda kullanılan matematik modelde, bağımlı ve bağımsız değişkenlerin ne olacağ 1 şu ana kadar yapılan hesaplamalar ile belirlenmiş durumdadır; ancak hangi bağımlı ve bağımsız değişkenlerin uygun olduğu ile ilgili herhangi bir analiz yapılmamıştır. Regresyon temeline dayanan çok değişkenli yöntemlerin ilk adımı çalışmaya alınacak uygun bağımlı ve bağımsız değişkenlerin belirlenmesidir. Her iki tür değişkenin belirlenmesi kavramsal ve kuramsal temellere dayandırılmalıdır. Araştırmacıların kendi yargılarını ve bilgi birikimini ortaya koymadan belirleme yaptığ bazı temel ilkelerinin dikkate alınmadığı söylenebilir. Regresyon çözümlemesinde bağımlı değişkenin seçilmesinde önemli bir sorun, değişkende ortaya çıkan sorun ölçüm hatası sorunudur. Ölçüm hataları, veri girişi hatalarından ölçümlerin kararsızlığına kadar birçok nedenle ortaya çıkabilir. Yapılan çalışmada bağımlı değişkende ölçüm hatasının yapılmadığı kabul edilmektedir. Bağımsız değişkenlerin seçiminde ise önemli sorun, birçok değişken arasından ilgisiz değişkenlerin modele alınması, birçok ilgili değişkenin ise model dışı bırakılmasıdır.

\subsubsection{Temel Elemanlar Arasındaki Çoklu Doğrusallık}

Regresyon çözümlemesine başlamadan önce tüm değişkenlere ilişkin korelasyon matrisinin incelenmesinde yarar vardır. Böylece bağımsız değişkenler arasında kuvvetli ilişki olup olmadığ 1 kolayca incelenebilir. Çünkü bağımsız değişkenler arasında yüksek ilişki olması çoklu regresyonun önemli sorunlarından biri olan çoklu bağlantı sorununa neden olmaktadır. Ayrıca bir değişkenin çoklu regresyon modelinde göreceli olarak neden önemsiz olduğu konusunda da bu matristen yararlanabilir. Önemsizliğin nedeni, ilgili değişkenin bağımlı değişken ile ilişkisinin olmaması olabileceği gibi bağımsız değişkenlerin kendi aralarında yüksek ilişki göstermesi de olabilir.

STTG yönteminin en önemli özelliğinin temel elemanlar arasında ortogonallik olduğu belirtilmişti. Çünkü temel elemanlar arasında ortogonallik olması durumunda STTG katsayıları etkin olmaktadır ve yorumu kolaylaştırmaktadır. Değişkenler arasında ortogonalliğin bozulması yani ilişki olması durumunda çoklu bağlantı sorunu gündeme gelmektedir. Bu da kurulan regresyon modeli ile yapılacak çıkarsamalarda yanlış yönlendirmelere ve hatalara neden olur. Örneğin verilerde çok küçük bir değişiklik yapıldığında katsayılarda büyük değişiklikler olur.

Çoklu bağlantıyı saptayabilmek için literatürde farklı teknikler önerilmiştir. Bu yöntemler korelasyon matrisinin incelenmesi, varyans şişirme değerleri, $\left(A^{\prime} A\right)$ 'nın özdeğerözvektör analizi, ( $\left.A^{\prime} A\right)^{\prime}$ 'nın determinantının hesaplanması, $\left(A^{\prime} A\right)^{\prime}$ 'nın koşul sayısının ve indislerinin belirlenmesi, varyans ayrışım oranları, bazı durumlarda temel katsayıların işaretleri ve büyüklüklerinin incelenmesi gibi yöntemlerdir. $\mathrm{Bu}$ yöntemlerin istenen özellikleri, çoklu bağlantı sorunun boyutunu gösterebilme ve hangi bağımsız değişkenlerin dâhil olduğunu belirlemeye yardımcı olacak bilgi sağlayabilmedir.
Çoklu bağlantıyı saptamada kullanılan göstergelerden birincisi temel elemanlar arasındaki korelasyon katsayısıdır. En basit şekilde iki temel eleman arasındaki korelasyon katsayısının bire yakın olması (yaklaşık 0.8 'in üzerinde olması) çoklu bağlantının yüksek olduğuna bir işarettir.

Çoklu bağlantıyı saptamada kullanılan göstergelerden ikincisi, varyans şişirme değerleridir. Bağımsız değişkenlere ilişkin korelasyon matrisinin tersinin köşegen öğelerine varyans şişirme değerleri denmektedir. Varyans şişme değerleri, iki veya daha fazla çoklu bağlantının varlığını göstermede yararlı olabilecek en iyi ölçütlerden birisidir. Varyans şişirme değerinin, 5'in altında olması zayıf çoklu bağlantının, 5 ile 30 arasında olması orta derecede çoklu bağlantının ve 30'un üzerinde olması ise çok güçlü çoklu bağlantının olduğunun göstergesidir [66, 46].

Çoklu bağlantıyı saptamada kullanılan göstergelerden üçüncüsü korelasyon matrisine ilişkin özdeğerlerin incelenmesidir. Temel elemanlarda bir veya daha fazla yakın doğrusal bağımlılık olduğunda temel elamanlar korelasyon matrisinin özdeğerlerinin biri veya daha fazlasının değeri sıfır veya sıfıra yakın olur. Bu kapsamda geliştirilmiş çeşitli yöntemler olmasına rağmen sıklıkla kullanılan iki yöntem bulunmaktadır. $\mathrm{Bu}$ yöntemlerden bir tanesi bulunan özdeğerlerinin terslerinin toplamının değişken sayısına eşit olmasıdır. Çoklu bağlantının olması durumunda bu değer çok büyük değerlere ulaşır. Diğer yöntem ise özdeğer yelpazesindeki yayılımın bir ölçüsü olan durum ya da koşul sayısı olarak adlandırılır. $\mathrm{Bu}$ değer temel elemanları korelasyon matrisinde elde edilen en büyük özdeğerin en küçük özdeğere bölünmesi ile bulunur. Bulunacak bu rakam eğer 100'ün altında olması çoklu bağlantının olmadığının, 100 ile 1000 arasında olması orta dereceli çoklu bağlantının olduğununun ve 1000'in üzerinde olması ise ciddi çoklu bağlantının olduğunun bir göstergesidir.

Buraya kadar literatürde oldukça yaygın olarak kullanılan yöntemler anlatılmıştır. Diğer tanılama yöntemleri de bu yöntemler kadar önemlidir. Bu yöntemlerle ilgili detaylı bilgilere Montgomery, Peck ve Vining (2012) [69] tarafından hazırlanan eserden ulaşılabilir.

Çoklu doğrusallığın varlığının saptanması aslında işin yarısıdır. İşin öbür yarısı ise çoklu bağlantının nasıl giderileceğidir. Tanılama yöntemlerinde olduğu gibi burada da kesin bir yöntem yoktur. Yalnızca bazı gevşek kurallar bulunmaktadır. Bu kurallardan bazıları, önsel bilgilerden yararlanmak, kesit ve zaman serilerini bir araya getirmek, yüksek ortak doğrusallık gösteren bir değişkeni dışlamak, verileri dönüştürmek, faktör analizi [46], ek veya yeni veri toplamak, ridge regresyonu ve temel bileşenler regresyonu [40] gibi yöntemlerdir. $\mathrm{Bu}$ kurallardan hangisinin işe yarayacağı, kuşkusuz verinin niteliğine ve ortak doğrusallık sorununun ciddiliğine bağlıdır [46].

Literatürde ridge regresyonu, temel bileşenler regresyonu ile faktör analizine "yanlı kestiriciler" denmektedir. Yanlı kestiricileri incelemek ve hangi işlemlerin en iyi şekilde 
işlediğini belirlemeye yönelik Monte Carlo benzetim çalışmaları yürütülmüştür. Bu kapsamda örnek olarak Hoerl ve Kennard (1970)'in [71] en küçük kareler ve ridge regresyonunu karşılaştırdığ 1 çalışma ve Gunst ve Mason (1977)'1n [72] ridge regresyonu, temel bileşenler regresyonu ve gizil kök yöntemini karşılaştırdığı çalışma verilebilir. Ancak yapılan bu çalışmalarda ortaya tek bir en iyi yöntem çıkmazken yanlı yöntemlerin en küçük karelerden üstün olduğu çok kez ortaya konmuştur. Ayrıca, Padilla (2005) [66] tarafindan yapılan çalışmada, yanlı tahmin tekniklerinden elde edilen STTG katsayıları karşılaştırılmıştır.

Daha önce belirtildiği üzere yukarıda anlatılan yöntemlerden bir tanesi değişkenler arasında korelasyona bakmaktır. Bu kapsamda altı temel eleman arasındaki korelasyon matrisi Tablo 8'de yer almaktadır.

Tablo 8. Altı Adet STTE Arasındaki Korelasyon Matrisi

\begin{tabular}{|c|c|c|c|c|c|}
\hline 1 & 0.497 & 0.309 & 0.694 & 0.402 & -0.67 \\
\hline 0.497 & 1 & 0.976 & -0.12 & 0.982 & -0.65 \\
\hline 0.309 & 0.976 & 1 & -0.31 & 0.984 & -0.50 \\
\hline 0.694 & -0.12 & -0.31 & 1 & -0.16 & -0.29 \\
\hline 0.402 & 0.982 & 0.984 & -0.16 & 1 & -0.52 \\
\hline $\mathrm{L}-0.67$ & -0.65 & -0.50 & -0.29 & -0.52 & 1 \\
\hline
\end{tabular}

Tablo 8'de yer alan temel elemanlar arasındaki korelasyon matrisi incelendiğinde ikinci ve üçüncü hurda/hata kaynakları arasında (0.976), ikinci ve beşinci hurda/hata kaynakları arasında (0.982) ve üçüncü ve beșinci hurda/hata kaynakları arasında (0.984) çok yüksek ilişki bulunmaktadır. Dolayısıyla modelde bu değişkenler arasında çoklu bağlantı probleminin olduğuna dair bir delil elde edilmiştir.

Çoklu bağlantının göstergelerinden diğeri varyans şişme değerleridir. $\mathrm{Bu}$ kapsamda altı temel eleman arasındaki korelasyon matrisinin cebirsel tersi, Tablo 9'da verilmiştir.

Tablo 9. Alt1 Temel STTE Arasındaki Korelasyon Matrisinin Cebirsel Ters Matrisi

$\mathrm{V}=\left[\begin{array}{cccccc}536 & -1611 & -1812 & -787 & 2844 & -337 \\ -1611 & 6681 & 1714 & 1746 & -6734 & 1101 \\ -1812 & 1714 & 14177 & 4014 & -13732 & 1005 \\ -787 & 1746 & 4014 & 1385 & -4874 & 475 \\ 2844 & -6734 & -13732 & -4874 & 17279 & -1741 \\ -337 & 1101 & 1005 & 475 & -1741 & 221\end{array}\right\rfloor$

Tablo 9'un köşegen değerleri bize VIF değerlerini vermektedir. VIF değerleri incelendiğinde bütün değişkenlerin VIF değerinin otuzun üzerinde olduğu görülmektedir. Dolayısıyla bütün değişkenler çok yüksek çoklu bağlantıdan etkilendiği sonucuna varılmıştır. En az etkilenen değişken altıncı temel eleman en çok etkilenen eleman ise üçüncü temel elemandır.

Çoklu bağlantının göstergelerinden diğeri korelasyon matrisine ilişkin özdeğerlerin incelenmesidir. Bu kapsamda temel elemanlar korelasyon matrisinden elde edilen özdeğerler Tablo 10’da gösterilmiştir.
Tablo 10. Altı Adet STTE'lere Ait Özdeğerler

\begin{tabular}{|l|l|}
\hline 1.Hurda/Hata Kaynağ1 Özdeğeri & 3.673 \\
\hline 2.Hurda/Hata Kaynağ1 Özdeğeri & 1.834 \\
\hline 3.Hurda/Hata Kaynağı Özdeğeri & $3.778^{*} \mathrm{e}-01$ \\
\hline 4.Hurda/Hata Kaynağ1 Özdeğeri & $1.136^{*} \mathrm{e}-01$ \\
\hline 5.Hurda/Hata Kaynağ Özdeğeri & $1.392^{*} \mathrm{e}-04$ \\
\hline 6.Hurda/Hata Kaynağ1 Özdeğeri & $3.022 \mathrm{e}-05$ \\
\hline
\end{tabular}

Birinci yönteme göre hesaplanacak olunursa, $1 / 3.673+1 / 1.834+1 / 3.778 * \mathrm{e}-01+1 / 1.136 * \mathrm{e}-01+1 / 1.392 * \mathrm{e}-$ $04+1 / 3.022 \mathrm{e}-05=40286.84$ değerine ulaşılır. $\mathrm{Bu}$ değer değişken sayısı olan 6 değerinin oldukça üzerindedir. Koşul indeksi ise 3.673/3.022e-05=121535 şeklinde hesaplanır. Bu duruma bakıldığında beşinci ve altıncı hurda/hata kaynaklarının değerlerinin sıfıra yakın olması, özdeğerlerinin terslerinin toplamı 6 değerinin çok üzerinde olması ve koşul indeksinin değerinin 1000'den büyük olması çoklu bağlantının var olduğunun bir diğer göstergesidir.

Bir diğer çoklu bağlantının ölçüsü değişkenler arasındaki korelasyon matrisinin determinantına bakılmasıdır. Elde edilen değer 1'e yakınsa çoklu bağlantının olmadığını ve sıfıra yakınsa çoklu bağlantının olduğunu ortaya koyar. Temel elemanlar korelasyon matrisinin determinant alındığında 1.218114e-09 değeri elde edilir. Dolayısıyla bu modelde çoklu bağlantı olduğunu gösterir.

Çoklu bağlantının giderilmesi için önerilen birçok yöntem ile ilgili detaylı bilgiler çalışmanın ikinci bölümünde verilmiştir. $\mathrm{Bu}$ yöntemlerden en çok kullanılanları veriye yeni gözlemlerin eklenmesi, modelin yeniden belirlenmesi ve en küçük kareler yöntemi dışında diğer kestirim yöntemlerinin kullanılmasıdır.

Çoklu bağlantının bağımsız değişkenler arasındaki gerçek ilişki nedeniyle ortaya çıktığı durumlarda diğer bir deyişle, sorunun bir örnekleme sorunu olmadığı durumlarda önerilen yöntemlerden birisi, çoklu bağlantılı değişkenlerden birisi veya daha fazlasını modelden çıkarmak başka bir deyişle değişken seçimi yapmaktır. Ancak modelden değişken çıkartma yöntemi, örneklemin evreni temsil etmemesi nedeniyle ortaya çıkan durumlarda kullanılmamalıdır. Çünkü modele gerçekten katkı yapabilecek bir değişken çoklu bağlantı nedeniyle model dişı bırakılabilir. $\mathrm{Bu}$ çalışmada ortaya konan modelde değişkenlerin VIF değerlerine, değişkenler arasındaki korelasyon yapısına ve özdeğerlere bakılarak yapılan değerlendirme sonucunda modelde ciddi çoklu bağlantı sorununun olduğu görülmektedir. $\mathrm{Bu}$ kapsamda Tablo 11'de yer alan korelasyon matrisine göre modelden değişken çıkarma yöntemi uygulandığında yani modelden çoklu bağlantıya sebep veren ikinci ve beşinci hurda/hata kaynakları çıkartıldığında elde edilen korelasyon matrisi, VIF değerleri ve özdeğerler Tablo 11'de, Tablo 12'de, Tablo 13'te ve Tablo 14'te sunulmuştur. 
Tablo 11. Dört Adet STTE'nın Arasındaki Korelasyon Değerleri

$$
\mathrm{R}=\left[\begin{array}{cccc}
1 & 0.309 & 0.694 & -0.673 \\
0.309 & 1 & -0.315 & -0.506 \\
0.694 & -0.315 & 1 & -0.292 \\
-0.673 & -0.506 & -0.292 & 1
\end{array}\right]
$$

Tablo 12. Dört Adet STTE'nın VIF Değerleri

$$
\mathrm{V}=\left[\begin{array}{cccc}
5.462 & 2.350 & 4.157 & 1.270 \\
2.350 & 2.972 & 2.780 & 0.735 \\
4.157 & 2.78 & 4.758 & 0.0007 \\
1.270 & 0.735 & 0.0007 & 2.227
\end{array}\right]
$$

Tablo 13. Dört Adet STTE'nın Özdeğerleri

\begin{tabular}{|l|l|}
\hline 1.Hurda/Hata Kaynağı Özdeğeri & 10.959 \\
\hline 3.Hurda/Hata Kaynağı Özdeğeri & 3.289 \\
\hline 4.Hurda/Hata Kaynağı Özdeğeri & 0.719 \\
\hline 6.Hurda/Hata Kaynağı Özdeğeri & 0.451 \\
\hline
\end{tabular}

Tablo 14. Dört Adet STTE'nın Koşul İndeksi

\begin{tabular}{|l|l|}
\hline $1 / 10.959+1 / 3.289+1 / 0.719+1 / 0.451$ & 4.003 \\
\hline
\end{tabular}

Ayrica yeni temel elemanlar korelasyon matrisinin determinantı ise 0.08538267 olarak hesaplanmıştır. Bu değer 6 temel elemanın bulunduğu korelasyon matrisi ile karşılaştırıldığında yeni oluşturulan temel elemanlar korelasyon matrisinin determinant 6 temel elemanl korelasyon matrisinin determinantına (1.218114e-09) göre, 1 değerine çok yakın olduğu görülmektedir.

Temel elemanlar matrisinden iki adet temel eleman çıkartıldığında temel elemanlar arasında oluşan korelasyon matrisi elemanları arasında yüksek korelasyon değerlerinin olmadığı görülmüş ve bu kapsamda oluşan yeni STTE'ler Tablo 15'te ve yeni STTE'lerin değerleri ise Tablo 16'da sunulmuştur.

Tablo 15. Dört Adet STTE Matrisinin Elemanları ve Değerleri

\begin{tabular}{|l|l|}
\hline STTE-1 & MS 58 (Ara iş) \\
\hline STTE-3 & Hurda Radyatör \\
\hline STTE-4 & Reganya Toprak \\
\hline STTE-6 & $\begin{array}{l}\text { Harici Pirinç ve Bronz Talaşı } \\
\text { Harici Pirinç ve Bronz Hurdası }\end{array}$ \\
\hline
\end{tabular}

Tablo 16. Dört Adet STTE Matrisinin Elemanları ve Değerleri

\begin{tabular}{|l|l|l|l|l|}
\hline Element & 1. STTE & 2. STTE & 3. STTE & 4. STTE \\
\hline $\mathrm{Cu}$ & 0 & 13 & -0.5 & -0.5 \\
\hline $\mathrm{Pb}$ & -1 & 0 & -1 & 1 \\
\hline $\mathrm{Fe}$ & -0.235 & -0.03 & 0.35 & -0.03 \\
\hline $\mathrm{Sn}$ & -0.185 & 1.02 & 0.05 & 1.02 \\
\hline $\mathrm{Al}$ & -0.025 & -0.025 & 0.05 & 0.05 \\
\hline $\mathrm{Ni}$ & -0.235 & -0.03 & -0.125 & -0.03 \\
\hline $\mathrm{Sb}$ & 0 & 0 & -0.0087 & 0.0025 \\
\hline
\end{tabular}

\subsection{Model Geçerliliğinin Kontrol Edilmesi}

Regresyon analizinde model geçerliliği, amaçlanan çalışma ortamında modelin başarılı bir fonksiyon olup olmadığına karar vermeye yönlendiren bir incelemedir. Bu kapsamda STTG yöntemindeki en küçük kareler ile hesaplanan matematiksel modelin pirinç üretim süreci için uygun bir fonksiyon olup olmadiğ ilk olarak katsayıların artı işareti $(+)$ o hurda cinsinden fazla atılmayı, eksi işareti (-) ise o hurda cinsinden eksik atılmayı simgelemektedir. Her bir hurda cinsinden çalışanlar şarja hurdalardan eksik veya fazla atabilme kabiliyetine sahip olmalarından dolayı katsayılar eksi veya artı olabilir. Dolayısıyla bu incelemenin, kurulan modelde çok anlamlı olmadığı görülmüştür. Modelin yeterliliği ile ilgili olarak diğer bir kıstas modeldeki STTE'ler arasındaki VIF değerlerine bakmaktır. Modelin yeterliliği ile ilgili olarak çoklu bağlantı problemi incelendiğinde, çoklu bağlantı problemi ortadan kaldırıldığından, yani VIF değerlerinin 0 ile 10 değerleri arasında olmasından dolayı bu kriterlere göre modelin pirinç üretim süreci açısından geçerli bir model olduğuna karar verilmiştir (Her STTG katsayısı için VIF değerleri: $5.34,6.12$, 3.87 ve 4.41). Kurulan modelin amacı kestirim olmadığından, söz konusu modelin geçerliliğin kontrolü için yapılması gereken diğer kontrollerden yeni gözlem verisi toplama ve modelin kestirim için test edilmesi ve verileri yarıya bölme işlemleri bu çalışmada yapılmamıştır.

\section{KALITTE KARAKTERISTIKLERININ $I, R, E W M A$ VE HOTELLING $T^{2}$ KONTROL GRAFIKLERİ İLE IZLENMESI}

STTG katsayılarının hesaplanması, R programlama dilinde yapılan kodlamalar ile yapılmıştır. STTG katsayılarının hesaplanması ile ilgili detaylı bilgiler Orçanlı (2017) [70] tarafından hazırlanmış yayına bakılabilir.

STTG katsayılarının tek ve çok değişkenli kontrol grafiklerinde izlenebilmesi için öncelikle tek ve çok değişkenli normallik varsayımını sağlaması gerekmektedir. $\mathrm{Bu}$ kapsamda $\mathrm{R}$ programlama dilinde söz konusu varsayımlarının kontrolü için tek değişkenli normallik varsayımının kontrolü için Anderson testi ve çok değişkenli normallik kontrolü için Henze Zirkler testi yapılmıştır. Yapılan tek değişkenli normallik testi sonucunda birinci, ikinci ve dördüncü STTG katsayılarının tek değişkenli normal dağıldığ 1 ( $p(0.065), p(0.12), p(0.08)>0.05)$ ancak üçüncü STTG katsayının normal dağılmadığı $(p(0.01)<$ 0.05) tespit edilmiştir. Bunu üzerine üçüncü STTG katsayısının verilerine log normallik dönüşümü uygulandıktan sonra normal dağılması $(p(0.12)>0.05)$ sağlanmıştır. Müteakiben bu veriler ile yapılan çok değişkenli normal dağılım testi sonucunda da dört katsayıya ait verilerin çok değişkenli normal dağıldığı (HZ: 9.182, $p(0.12)>0.05$ ve MVN:TES) görülmüştür.

\subsection{I ve $M R$ Kontrol Grafikleri ile İzlenmesi;}

\subsubsection{Faz I (I Kontrol Grafikleri)}

İlk olarak STTG katsayılarının Faz I aşaması için düzenlenen I kontrol grafikleri ve bu kontrol grafiklerinde tespit edilen kontrol dışı sinyaller hesaplanmıştır. Bu kapsamda $I$ kontrol 
grafiğinin Faz I aşamasından elde edilen ve Faz II aşaması esnasında kullanılacak STTG katsayılarının ortalama değerleri ile standart sapma değerleri ise Tablo 19'dadır.

Tablo 17. STTG Katsayıları için I Kontrol Grafiği Faz I Așaması Parametreleri

\begin{tabular}{|c|c|c|c|}
\hline$S_{Z_{11}}$ & 0.1683 & $\bar{X}_{Z_{11}}$ & 1.1213 \\
\hline$S_{Z_{12}}$ & 0.081035 & $\bar{X}_{Z_{12}}$ & 0.04584 \\
\hline$S_{Z_{13}}$ & 0.00001 & $\bar{X}_{Z_{13}}$ & 0.000016 \\
\hline$S_{Z_{14}}$ & 0.08350 & $\bar{X}_{Z_{14}}$ & 0.10361 \\
\hline
\end{tabular}

\subsubsection{Faz I (MR Kontrol Grafikleri)}

İlk olarak $I$ kontrol grafiğinde olduğu gibi STTG katsayılarının Faz I aşaması için düzenlenen $M R$ kontrol grafikleri ve bu kontrol grafiklerinde tespit edilen kontrol dış1 sinyaller hesaplanmıştır. Bu kapsamda $M R$ kontrol grafiğinin Faz I aşamasından elde edilen ve Faz II aşaması esnasında kullanılacak STTG katsayılarının standart sapma değerleri ise Tablo 18'de sunulmuştur.

Tablo 18. STTG Katsayıları için $M R$ Kontrol Grafiğgi Faz I Aşaması Parametreleri

\begin{tabular}{|l|l|}
\hline$S_{Z_{11}}$ & 0.15005 \\
\hline$S_{Z_{12}}$ & 0.08103 \\
\hline$S_{Z_{13}}$ & 0.000012 \\
\hline$S_{Z_{14}}$ & 0.101882 \\
\hline
\end{tabular}

\subsubsection{Faz II ( $I$ ve $M R$ Kontrol Grafikleri)}

\subsubsection{Birinci STTG Katsayısı $\left(\mathrm{Z}_{21}\right)$}

Birinci STTG katsayısı ile ilgili tasarlanan $I$ ve $M R$ kontrol grafikleri Şekil 9'da yer almaktadır.

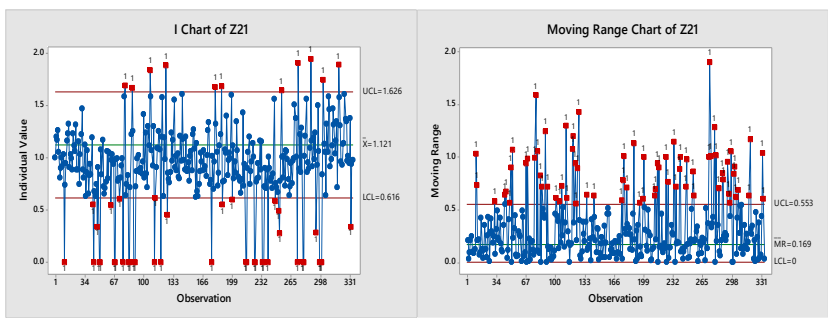

Şekil 9. Birinci STTG Katsayısı $\left(\mathrm{Z}_{21}\right)$ için Düzenlenen $I$ ve $M R$ Kontrol Grafiklerinin Faz II Aşamaları

\section{Değerlendirme:}

$I$ kontrol grafiği incelendiğinde 51 adet ve $M R$ kontrol grafiği incelendiğinde 72 adet kontrol dişı sinyalin olduğu tespit edilmiştir. Her iki kontrol grafiği ortak olarak değerlendirildiğinde, iki dönemde şarjın içine bu hurda grubundan eksik atıldığı söylenebilir. Kontrol dışı durumlar ile ilgili olarak yorumlar, söz konusu katsayı için tasarlanan EWMA kontrol grafiğinin durumuna bakılarak müşterek olarak yapılmıştır.

\subsubsection{2. İkinci STTG Katsayısı $\left(\mathrm{Z}_{22}\right)$}

İkinci STTG katsayısı ile ilgili tasarlanan I ve MR kontrol grafikleri Şekil 10'da yer almaktadır.

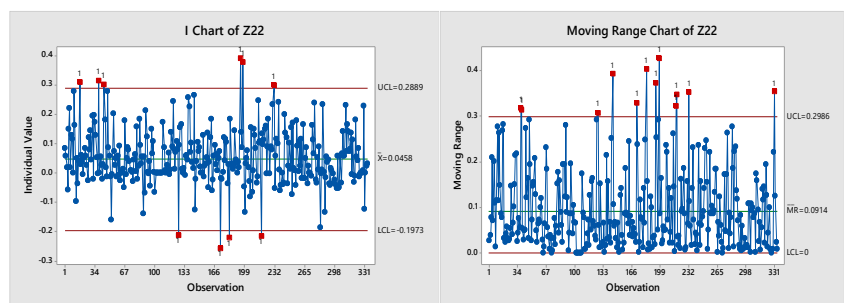

Şekil 10. İkinci STTG Katsayısı $\left(\mathrm{Z}_{22}\right)$ İçin Düzenlenen I ve MR Kontrol Grafiklerinin Faz II Aşamaları

\section{Değerlendirme:}

$I$ kontrol grafiği incelendiğinde 10 adet kontrol dışı sinyalin ve $M R$ kontrol grafiği incelendiğinde 54 adet kontrol diş1 sinyalin olduğu tespit edilmiştir. Her iki kontrol grafiği ortak olarak değerlendirildiğinde, rastgele zamanlarda ve az sayıda kontrol dışı sinyalin olduğu söylenebilir. Kontrol dışı durumlar ile ilgili yorumlar, söz konusu katsayı için tasarlanan EWMA kontrol grafiğinin durumuna bakılarak müşterek olarak yapılmıştır.

\subsubsection{3. Üçüncü STTG Katsayısı $\left(\mathrm{Z}_{23}\right)$}

Üçüncü STTG katsayısı ile ilgili tasarlanan $I$ ve $M R$ kontrol grafikleri Şekil 11'de yer almaktadır.

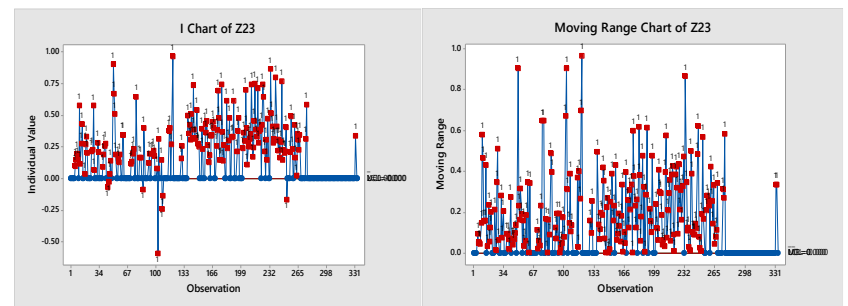

Şekil 11. Üçüncü STTG Katsayısı $\left(\mathrm{Z}_{23}\right)$ İçin Düzenlenen $I$ ve $M R$ Kontrol Grafiklerinin Faz II Aşamaları

\section{Değerlendirme:}

$I$ kontrol grafiği incelendiğinde 169 adet kontrol dışı sinyalin ve $M R$ kontrol grafiği incelendiğinde, 205 adet kontrol diş1 sinyalin olduğu tespit edilmiştir. Her iki kontrol grafiği ortak olarak değerlendirildiğinde, bu hurda grubundan şarjın içine devamlı olarak fazla atıldığı söylenebilir. Hata kaynağına yönelik olarak yapılan inceleme neticesinde, bu hurda grubunda bulunan hurdaların ufak parçalara ayrılamamasından kaynaklandığı tespit edilmiş ve bu hurdaların dökümhaneye giden araca tam sığamadığı görülmüştür. Grafiğinin son bölümlerinde hiç kontrol dışı sinyalin olmamasının nedeni ise aynı grupta aynı özellikleri taşıyan başka hurda cinsinin kullanılmasından kaynaklanmıştır. 


\subsubsection{Dördüncü STTG Katsayısı $\left(\mathrm{Z}_{24}\right)$}

Dördüncü STTG katsayısı ile ilgili tasarlanan $I$ ve $M R$ kontrol grafikleri Şekil 12'de yer almaktadır.

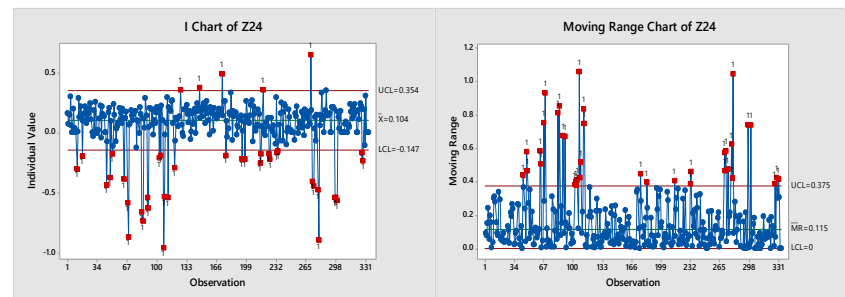

Şekil 12. Dördüncü STTG Katsayısı $\left(\mathrm{Z}_{24}\right)$ İçin Düzenlenen $I$ ve $M R$ Kontrol Grafiklerinin Faz II Aşamaları

\section{Değerlendirme:}

$I$ kontrol grafiği incelendiğinde 31 adet kontrol dișı sinyalin ve $M R$ kontrol grafiği incelendiğinde 37 adet kontrol dişı sinyalin olduğu tespit edilmiştir. Her iki kontrol grafiği ortak olarak değerlendirildiğinde, hurda cinsinden şarj içine genel olarak eksik atılma durumunun oluştuğu söylenebilir. Kontrol dışı durumlar ile ilgili olarak yorumlar, söz konusu katsayı için tasarlanan EWMA kontrol grafiğinin durumuna bakılarak müşterek olarak yapılmıştır.

\subsection{EWMA Kontrol Grafiği ile İzlenmesi}

STTG katsayılarının izlendiği $I$ ve $M R$ kontrol grafiklerine bakıldığında izlenen değişkenlerde kaymaların büyük olduğu ancak kontrol sınırlarına oldukça yakın fazla değerlerinde olduğu tespit edilmiştir. Kontrol sınırlarına yakın olan değerlerin davranışlarını tam olarak tespit etmek ve ufak kaymalarında durumlarını tam olarak görmek maksadıyla söz konusu katsayıların EWMA kontrol grafikleri ile izlenmesine ihtiyaç duyulmuştur.

\subsubsection{Faz I}

EWMA kontrol grafiğinin Faz I aşamasından elde edilen ve Faz II aşaması esnasında kullanılacak STTG katsayılarının ortalama değerleri ile standart sapma değerleri Tablo 19'da verilmiştir.

Tablo 19. STTG Katsayılarının EWMA Kontrol Grafiği'nin Faz I Aşaması Parametreleri

\begin{tabular}{|c|c|c|c|}
\hline$S_{Z_{11}}$ & 0.30236 & $\bar{X}_{Z_{11}}$ & 1.04579 \\
\hline$S_{Z_{12}}$ & 0.0810 & $\bar{X}_{Z_{12}}$ & 0.04584 \\
\hline$S_{Z_{13}}$ & 0.0704 & $\bar{X}_{Z_{13}}$ & 0.0495 \\
\hline$S_{Z_{14}}$ & 0.11192 & $\bar{X}_{Z_{14}}$ & 0.076048 \\
\hline
\end{tabular}

\subsubsection{Faz II}

\subsubsection{Birinci ve İkinci $S T T G$ Katsayıları $\left(Z_{21}\right.$ ve $\left.Z_{22}\right)$}

Birinci ve ikinci STTG katsayıları $\left(Z_{21}\right.$ ve $\left.Z_{22}\right)$ için tasarlanan EWMA kontrol grafikleri Şekil 13'te yer almaktadir.

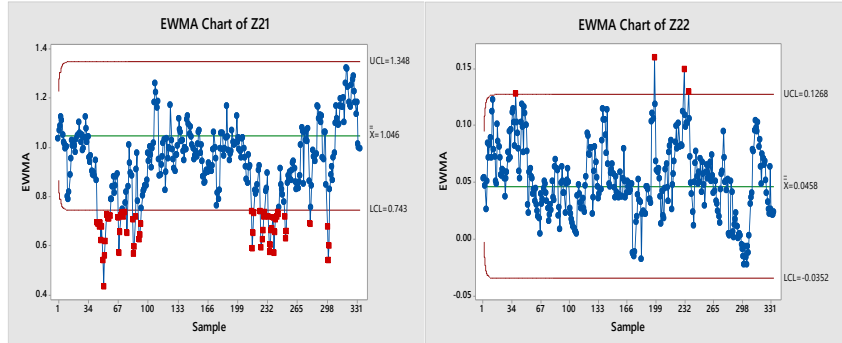

Şekil 13. Birinci ve İkinci STTG Katsayıları $\left(\mathrm{Z}_{21}\right.$ ve $\left.\mathrm{Z}_{22}\right)$ İçin Düzenlenen EWMA Kontrol Grafiklerinin Faz II Aşamas1

\section{Değerlendirme:}

Birinci ve ikinci STTG katsayıları $\left(Z_{21}\right.$ ve $\left.Z_{22}\right)$ için tasarlanan, Şekil 13 'te yer alan EWMA kontrol grafikleri incelendiğinde, birinci STTG katsayısı kontrol grafiğinde 14 adet ve ikinci STTG katsayısı kontrol grafiğinde ise üç adet kontrol dişı sinyalin olduğu tespit edilmiştir. Kontrol dişı sinyaller ile ilgili olarak hata kaynağının tespitine yönelik olarak yapılan inceleme sonucunda, ikinci STTG katsayısı kontrol grafiğinde farklı zamanlarda az sayıda meydana gelen kontrol dişı sinyallerin personel hatasından (çalışan personelin dikkatsizliği ve işine gerekli özen vermemesinden) kaynaklandığı, birinci STTG katsayısı kontrol grafiğinde ise belli dönemlerde oluşan kontrol diş1 sinyallerin ise tartının arıza yapmasından (birinci kontrol dışı sinyal grubunun hata kaynağı) ve personel hatası ile kullanılan hurda cinslerinden (ikinci kontrol dışı sinyal grubunun hata kaynağı) kaynaklandığı değerlendirilmiştir. Ancak bu dönemlerde birinci STTG katsayısını temsil eden hurda grubunda belirlenen dönemde eksik atılma durumu ile karşı karşıya gelindiği ve MS58 cinsi pirinç üretimine neden olan bilinen hata kaynağı olarak karşımıza çıkmıştır.

\subsubsection{2. Üçüncü ve Dördüncü STTG Katsayıları $\left(Z_{23}\right.$ ve $\left.Z_{24}\right)$}

Üçüncü ve dördüncü STTG katsayıları $\left(Z_{23}\right.$ ve $\left.Z_{24}\right)$ için tasarlanan EWMA kontrol grafikleri Şekil 14'te yer almaktadır.

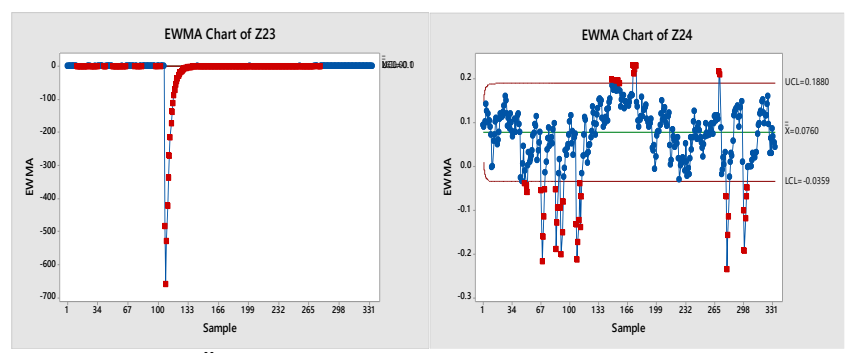

Şekil 14. Üçüncü ve Dördüncü STTG Katsayıları $\left(\mathrm{Z}_{23}\right.$ ve $\left.\mathrm{Z}_{24}\right)$ İçin Düzenlenen EWMA Kontrol Grafiğinin Faz II Aşaması

\section{Değerlendirme:}

Üçüncü ve dördüncü STTG katsayıları $\left(\mathrm{Z}_{23}\right.$ ve $\left.\mathrm{Z}_{24}\right)$ için tasarlanan Grafik 10'da yer alan EWMA kontrol grafikleri 
incelendiğinde, birinci STTG katsayısı kontrol grafiğinde 204 adet ve ikinci STTG katsayısı kontrol grafiğinde ise 43 adet kontrol dişı sinyalin olduğu tespit edilmiştir. Kontrol dışı sinyaller ile ilgili hata kaynağının tespitine yönelik olarak yapılan inceleme sonucunda, dördüncü STTG katsayısı kontrol grafiğinde belli dönemlerde oluşan kontrol dışı sinyallerin tartının arıza yapmasından (birinci kontrol dışı sinyal grubunun hata kaynağı) ve personel hatası ile kullanılan hurda cinslerinden (ikinci kontrol dışı sinyal grubunun hata kaynağı), üçüncü STTG katsayısı kontrol grafiğinde ise bu hurda grubunda bulunan hurdaların ufak parçalara ayrılamamasından kaynaklandığ değerlendirilmiştir. Ancak bu dönemlerde dördüncü STTG katsayısını temsil eden hurda grubunda eksik ve üçüncü STTG katsayısını temsil eden hurda grubunda ise fazla atılma durumu ile karşı karşıya gelindiği ve istenilen özeliklerde MS58 cinsi pirinç üretilememesine neden olan bilinen hata kaynağı olarak karşımıza çıkmıştır.

\subsection{STTG Katsayılarının $I, M R$ ve $E W M A$ Kontrol Grafikleri ile İlenmesi Sonucunda Elde Edilen Sonuçlar}

Birinci STTG katsayının izlendiği $I$ ve $M R$ kontrol grafiklerinde hurdaların eksik ve fazla atıldığı ancak eksik atılma miktarının fazla atılma miktarına göre daha fazla olduğu görülmektedir. Ancak yorumlama konusunda durum ile ilgili net karara varmak için kesinlik sağlayacak bilgiler elde edilememektedir. Ancak EWMA kontrol grafiğine bakıldığında eksik atılma durumu ile hangi dönemlerde bu durumun netleştiği net olarak görülmektedir. Konuyla ilgili olarak pirinç üretim sürecinde o esnada görevli kalite ve süreç uzmanları ile yapılan araştırmalar neticesinde, dönemsel olarak eksik atılan hurda grubunun eksik atılmasının nedeni olarak tartıdan kaynaklandığı tespit edilmiştir.

İkinci STTG katsayının izlendiği her üç kontrol grafiği birlikte değerlendirildiğinde bu hurda grubunda daha çok personelin anlık hatasından kaynaklandığı değerlendirilen çok az sayıda büyük kaymaların meydana geldiği tespit edilmiş ve süreci etkileyecek herhangi bir özel nedenin bulunmadığı düşünülmüştür. Konuyla ilgili olarak pirinç üretim sürecinde o esnada görevli kalite ve süreç uzmanları ile yapılan araştırmalar neticesinde, öngörülen değerlendirmenin doğru olduğu teyit edilmiştir.

Üçüncü STTG katsayının izlendiği $I$ ve $M R$ kontrol grafiklerinde hurda gruplarında büyük kaymalar tespit edilmiş ancak yorumlama konusunda net bilgiye ulaşılamamıştır. Ancak EWMA kontrol grafiğinde ise 100130 sayılı hurda grubunda eksik atılma tespit edilmiş ve zamanla süreçte alınan tedbirler gereği sürecin kontrol altına alındığ 1 düşünülmektedir. Konuyla ilgili olarak pirinç üretim sürecinde o esnada görevli kalite ve süreç uzmanları ile yapılan araştırmalar neticesinde kontrol dişı durumun terazinin 50-100 no'lu ölçümlerde bir arıza olduğunu ve ancak yanlış teşhis sonunda tadilattan dolayı tartıda daha büyük bir arıza meydana geldiği belirtilmiştir. Tartıda meydana gelen bu büyük arıza nedeniyle ve görevli personelin hatasından dolayı bu hurda grubundan eksik atıldığı belirtilmiştir.

Dördüncü STTG katsayının izlendiği $I$ kontrol grafiğinde bazı dönemlerde bu hurda grubunun eksik atıldığ görülmektedir, ancak dönemler tam olarak belirgin değildir. $M R$ kontrol grafiğinde ise kontrol dişı sinyallerin eksik atıldığı dönemler daha belirgindir. Ancak EWMA kontrol grafiğinde ise kontrol dişı sinyaller diğer kontrol grafiklerine göre hem daha belirgin hale gelmekte ve hem de hurdaların hangi dönemde eksik atıldığı kesin olarak daha iyi görülmektedir. Yapılan inceleme sonucunda eksik atılma dönemi olarak birinci STTG katsayılarının izlendiği 50-100 no'lu ölçümlerde aynı zamanda meydana gelmiş olmasından dolayı bu eksik atılma nedeninin tartıdan meydana gelmiş olduğu sonucuna ulaşılmıştır. Ulaşılan bu sonuç görevli personel ile yapılan araştırma neticesinde teyit edilmiştir.

\subsection{Hotelling $T^{2}$ Kontrol Grafiği ile İzlenmesi 5.4.1. Faz I}

STTG katsayılarının eş zamanlı olarak Hotelling $T^{2}$ kontrol grafiği ile izlenmesinde Faz I aşamasında her bir katsayıya ait 50 adet sayısal değer kullanılmıştır. Bu grafiklerden elde edilen parametreler diğer kontrol grafiklerinde açıklandığ gibi Faz II aşamasında kullanılacaktır. $\mathrm{Bu}$ kapsamda Hotelling $T^{2}$ kontrol grafiğinin Faz I aşamasında elde edilen ortalama vektörü, varyans-kovaryans matrisi ile korelasyon matrisi Tablo 20'de verilmiştir.

Tablo 20. Hotelling $T^{2}$ Kontrol Grafiği Faz I Aşaması Ortalama Vektörü, Varyans-Kovaryans Matrisi ile Korelasyon Matrisi

$$
\begin{gathered}
\overline{\boldsymbol{X}}_{\left.Z_{11}\right\rceil} 1.141 \\
\bar{X}=\overline{\boldsymbol{X}}_{Z_{12}}=0.0539 \\
\overline{\boldsymbol{X}}_{Z_{13}}=0.0813 \\
\left\lfloor\overline{\boldsymbol{X}}_{\left.Z_{14}\right\rfloor}\right\rfloor \\
\mathbf{Z}=\left[\begin{array}{cccc}
0.065082 & -0.00260 & -0.00864 & 0.001087 \\
-0.00260 & 0.006472 & 0.001508 & -0.00538 \\
-0.00864 & 0.001508 & 0.014158 & -0.00178 \\
0.001087 & -0.00538 & -0.00178 & 0.007507
\end{array}\right] \\
R=\left[\begin{array}{cccc}
1 & -0.127 & -0.285 & 0.049 \\
-0.127 & 1 & 0.158 & -0.772 \\
-0.285 & 0.158 & 1 & -0.173 \\
0.049 & -0.772 & -0.173 & 1
\end{array}\right]
\end{gathered}
$$

\subsubsection{Faz II}

STTG katsayıları için düzenlenen Hotelling $T^{2}$ kontrol grafiğinin Faz II aşaması gösterimi Şekil 15'te yer almaktadır. 


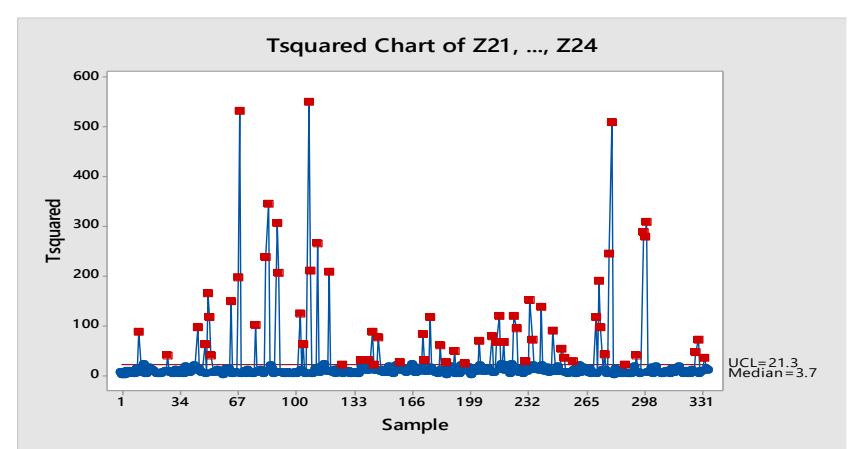

Şekil 15. STTG Katsayıları İçin Düzenlenen Hotelling $T^{2}$ Kontrol Grafiğinin Faz II Aşaması

\section{Değerlendirme:}

STTG katsayılarının eş zamanlı olarak Hotelling $T^{2}$ kontrol grafiği ile izlenmesinde sonucunda 54 adet kontrol dış1 sinyal tespit edilmiştir. Bu sinyallerin yorumlanması hususu ile ilgili daha önceki bölümlerde de açıklandığı gibi çeşitli araştırmacılar tarafindan ortaya konmuş yolların bulunduğu belirtilmiştir. Dolayısıyla tek değişkenli kontrol grafiklerinden yararlanılabileceği gibi kontrol grafiklerinde oluşan örüntü şekillerinin tanınması ile de yapılabilir. Şekil 15'te yer alan Hotelling $T^{2}$ kontrol grafiğ i incelendiğinde, 20 ile 54 nolu $T^{2}$ sinyallerinin yukarı eğim örüntü tipini oluşturduğu görülmektedir. Bu eğitim tipinin araştırılması ile ilgili olarak literatürde çeşitli yöntemler uygulanmaktadır. $\mathrm{Bu}$ problemin çözümü ile ilgili olarak Orçanlı (2017) [70] tarafından hazırlanmış doktora tezinde yapay sinir ağları ile ilgili olarak çözüm yer almaktadır.

\section{BULGULAR}

Yapılan çalışmada, günümüzde döküm sürecinde süreç kontrolünde kalite karakteristiği olarak üretilen nihai ürünün özellikleri ele alınırken, söz konusu ürün özellikleri yerine ürünün iç kompozisyonunu oluşturan element oranları da alınabileceği düşüncesi ile araştırma başlatılmıştır. Literatürde yapılan inceleme neticesinde söz konusu iddianın doğrulanabileceği görülmüştür. Ayrıca tespit edilen durum ile ilgili olarak üretim sürecinin kalite kontrolünde ise ürünün kompozisyonunda bulunan element oranlarının kalite kontrol grafikleri ile izlenebileceği ve yeterince başarılı sonuçları veremediği görülmüştür. Bu kapsamda problemin çözümü için yeni yöntemlerin tespit edilmesi ve uygulanması gerekir.

Yapılan çalışmada pirinç üretim sürecinde kaymaların genel olarak büyüklüğ̈̈ tam olarak kestirilemediğinden dolayı ilk olarak büyük kaymaların varlığı $I$ ve $R$ kontrol grafikleri ile ve müteakiben elde edilen sonuçlara göre küçük kaymaların varlığı ise EWMA kontrol grafiği ile araştırılmıştır. Ayrıca hata kaynakları arasındaki çoklu bağlantı problemi ve ilişki durumu da göz önünde bulundurularak en son olarak hata kaynakları Hotelling $T^{2}$ kontrol grafiği ile izlenmiş ve sürecin değişkenliğini etkileyen özel sebepler ile ilgili değerlendirme yapılmış ve elde edilen sonuçlar aşağıya çıkarılmıştır.

- $I$ ve $R$ kontrol grafiklerine göre; bir numaralı hata kaynağının süreç üzerinde sürecin başından sonuna kadar etkili olduğu ancak oldukça dağınık olduğu ve toplu bir görüntü oluşturmadığı, iki numaralı hata kaynağının süreç üzerinde çok az sayıda büyük kaymalara neden olduğu, üç numaralı hata kaynağının sürecin üzerinde sürecin başından sonuna kadar oldukça etkili olduğu (bir numaralı hata kaynağına göre daha yoğun) ve dört numaralı hata kaynağının süreç üzerinde 50-110 gözlemler arasında ve 170-270 gözlemler arasında dağınık olarak büyük kaymalara neden olduğu tespit edilmiştir.

- EWMA kontrol grafiğine göre; bir numaralı hata kaynağının süreç üzerinde 33-100 arasındaki ve 200-270 arasındaki gözlemlerde ufak kaymalara sebep olduğu tespit edilmiştir. Dolayisıyla $I$ ve $R$ kontrol grafiği ile beraber düşünüldüğünde bir numaralı hata kaynağının ağırlıklı olarak EWMA kontrol grafiği ile tespit edilen gözlemlerde bir numaralı hatanın oldukça etkin olduğu sonucuna ulaşılmış̧ır. İki numaralı hata kaynağının süreç üzerinde ufak kaymalara neden olmamaktadır. Dolayısıyla $I$ ve $R$ kontrol grafiği ile beraber düşünüldüğünde iki numaralı hata kaynağının süreç üzerinde etkisinin bulunmadığı ifade edilebilir. Üç numaralı hata kaynağının süreç üzerinde sürecin başından sonuna kadar etkin olduğu tespit edilmiştir. Dolayısıyla $I$ ve $R$ kontrol grafiği ile beraber düşünüldüğünde söz konusu elde edilen sonucun doğru olduğu sonucuna ulaşılmıştır. Dört numaralı hata kaynağının süreç üzerinde, bir numaralı hata kaynağında olduğu gibi 33100 arasındaki ve 200-270 arasındaki gözlemlerde ufak kaymalara sebep olduğu tespit edilmiştir. Dolayısıyla I ve R kontrol grafiği ile beraber düşünüldüğünde bu tespit doğrulanmaktadır. Ayrıca burada dikkat edilmesi gereken bir durumda bir, üç ve dört numaralı hata kaynakları arasında etkileşimin bulunduğu ancak bir ve dört numaralı hata kaynakları arasındaki etkileşimin diğerlerine göre daha kuvvetli olduğu sonucuna ulaşılabilir.

- Hotelling $T^{2}$ kontrol grafiğine göre; 50-100 arasında, 166263 arasında ve 270-293 arasında bir yoğunlaşma mevcuttur. Ancak bunların arasında dikkat çeken durum ise 190-230 gözlemleri arasında yukarı eğim hareketinin oluştuğudur. Dolayısıyla STTG değişkenleri arasında çoklu bağlantı olmayacak şekilde bir tedbir alınmaya gidilse bile (değişken azaltma veya birleştirme yoluyla) yine de STTG değiş̧enleri arasındaki düşük düzeyde çoklu bağlantının varlığında bile Hotelling $T^{2}$ kontrol grafiğinde kontrol dışı sinyallerin oluşabildiği tespit edilmiştir. Çok değişkenli kontrol grafiklerinde kontrol dişına sebep olan değişkenlerin tespitine yönelik literatürde yer alan çeşitli ayrıştırma metotları kullanılarak çalışmalar yapılmasına rağmen bu çalışmada ayrıca bir çalışma gösterilmemiştir. Aynı problem ile ilgili olarak Orçanlı (2017) [70] tarafindan hazırlanmış doktora tezinde yapay sinir ağları ile bir çözüm yöntemi yer almaktadir. 


\section{SONUÇ VE ÖNERILER}

Döküm üretim süreçlerinde çeșitli kalite kontrolü uygulamaları oldukça yaygın olarak kullanılmaktadır. Ancak bütün üretim süreçlerinde olduğu gibi döküm üretim süreçlerinde de uygulanan kalite kontrolü uygulamalarının geliştirilmesine ihtiyaç duyulmaktadır.

Günümüzde döküm üretim süreçlerinde kaliteyi büyük ölçüde erimiş metalin içine döküldüğü kalıpların türü ve hazırlanışındaki gösterilen özen belirlemektedir ve uygulamada genellikle çap, parlaklık ve uzunluk gibi üretilen nihai ürünün özellikleri (döküm hataları (casting defects)) kalite değişkenleri olarak kabul edilmektedir. Dolayısıyla üretim sürecinin değișkenliği de genellikle bu kalite karakteristikleri kullanılarak belirlenmektedir. Ancak literatür araştırması sonucunda eriyik halde bulunan karışımdan alınan numunelerin spektral analiz sonucunda eriyiğin içindeki element oranlarının da kalite karakteristiği olarak ele alınabileceği görülmüş ve bu kalite karakteristikleri istatistiksel kalite kontrol grafikleri ile izlenebileceği tespit edilmiştir. Bu kapsamda MKE Pirinç Fabrikası Müdürlüğünde halen uygulanan kalite geliştirme çabalarını geliştirmek amacıyla bir istatistik kalite kontrolü uygulaması yapılmıştır.

MKE Pirinç Fabrikası Müdürlüğünde eriyik halde bulunan metalin içindeki element oranlarına dayalı halen uygulanan bir kalite kontrolü yöntemi bulunmaktadır. Yapılan çalışmada, kalite geliştirme kapsamında bu element oranları, uygulanan yöntemden farklı olacak şekilde tek ve çok değişkenli kontrol grafikleri ile izlenmiş ve kontrol dışı sinyaller tespit edilmiştir. Kontrol grafikleri, döküm sanayisinde üretim sürecindeki değişimin görsel olarak sürekli izlenebilmesini sağladığından ve kolay uygulanmasından dolayı tercih edilmektedir. Tespit edilen kontrol dışı sinyal/sinyallerin hata kaynaği/kaynaklarının izlenen değişken ya da değişkenlere bağımlı olarak süreç uzmanlarına ve literatürde yer alan yöntemlere dayalı olarak yorumlama çalışmaları ile ilgili olumlu sonuçlara ulaşılamamıştır.

Hata kaynaklarının yorumlanması ile ilgili karşılaşıılan duruma karşı STTG yöntemine dayalı bir yöntem önerilmiştir. Önerilen model, pirinç, demir ve alüminyum döküm süreçlerinde kullanılabilecek genel bir modeldir. Bu model, bütün döküm süreçlerinde kullanılabilir ancak problemin durumuna göre özelleştirilmesi gerekir. Yapılan çalışmada, önerilen model kapsamında elde edilen sonuçlar aşağıya çıkarılmıştır.

- Literatürde yapılan çalışmalarda gerçek verilerin yönetimsel veya teknik sebeplerden dolayı elde edilmesi zor ve maliyetli olmasından genellikle benzetim yolu ile üretilmiş veriler kullanılmaktadır. Yapılan çalışmada, gerçek veriler kullanılmıştır.

- STTG yönteminin, imalat sanayinde geometrik sapmaların modellenmesinde başarılı bir şekilde kullanıldığı, ancak bunun proses (kimya, petro-kimya, döküm vb.) endüstrilerinde ve birbiriyle ilişki içinde olan kalite karakteristiklerin bulunduğu çok değişkenli endüstriyel üretim süreçlerinde uygulamasının olmadığı görülmüştür. Bu kapsamda yapılan çalışma ile söz konusu yöntemin yeni bir endüstri alanında uygulaması yapılmıştır.

- Ayrica;

* STTG yönteminin imalat sanayinde geometrik sapmaların modellenmesi dışında pirinç üretim sürecinde de hatta benzer alüminyum ve demir döküm süreçlerinde uygulanabileceği,

* Söz konusu yöntemin STTE'lerin pirinç üretim sürecinde nasıl elde edilebileceği ve matematiksel modelin nasıl oluşturulabileceği,

* Literatürde kurulan modellerde STTE'ler her zaman tam olarak ele alınmıştır, ancak bazı üretim süreçlerinde bu durumun tam olmadığı ve eksikte olabileceği ve bu durumda da söz konusu STTG yönteminin uygulanabileceği,

* STTG yönteminde hata vektörü olan A'nın kalite değişken sayısının hata kaynağı sayısına eşit veya fazla olması durumlarına karşı matematiksel modeller önerilmiştir, Ancak eksik olması durumunda hata kaynağı sayısının azaltılması konusunda çeşitli istatistiksel yöntemlerinde (adımsal regresyon yöntemi, genelleştirilmiş ters matris yöntemi, değişken azaltma yöntemleri) uygulanabileceği,

* STTG katsayılarının literatürde tek değişkenli kontrol grafikleri ile izlenebileceği belirtilmesine rağmen çok değişkenli kontrol grafikleri ile de izlenebileceği görülmüştür.

\subsection{Yöntemi Geliştirmeye Dair Elde Edilen Sonuçlar}

Yapılan çalışmada çok değiş̧kenli kontrol grafiklerinde tespit edilen kontrol dışı sinyallerin yorumlanması konusunda STTG yöntemine dayalı bir adet model önerilmiştir. Söz konusu önerilen modelin geliştirilmesi ile ilgili elde edilen sonuçlar aşağıda sunulmuştur.

- STTG yöntemi, lineer çoklu regresyon yöntemine dayanmaktadır. Regresyonun klasik varsayımlarından bir tanesi gözlem sayısının tahmin edilecek anakütle katsayılarından fazla olmasıdır. Yani gözlem sayısı açıklayıcı değişken sayısından büyük olmalıdır. Eğer bu varsayım sağlanmazsa en küçük kareler yöntemi uygulansa bile katsayılar yanlı olmaktadır. Bu kapsamda STTG yöntemi değerlendirildiğinde; hataların gözlem sayısı hata kaynağı sayısından küçük olması durumunda, literatürde herhangi bir yöntem önerilmemiştir. Yapılan çalışmada böyle bir durum ile karşılaşılmış ve değişken sayısı indirme yöntemlerinden olan "modelin yeniden belirlenmesi" yöntemi kullanılmış ve değişken sayısı indirgenerek söz konusu model tekrar tanımlanmış ve modelin uygulanabilirliği ortaya konmuştur. Ayrıca böyle 
durumlarda adımsal (stepwise) regresyon modeli/modelleri de kullanılabilir.

- Regresyon analizinde regresyon katsayıları, siradan en küçük kareler yöntemi ile elde edilmektedir. Ancak bir matrisin determinantı sıfıra eşit olduğunda yani matris tekil bir matris olduğunda tersi alınamamaktadır. Bu kapsamda sıradan en küçük kareler yönteminde, $(\mathrm{X})$ tekil olduğunda tersi alınamamaktadır. Çalışmada öyle bir durum ile karşılaşılmamıştır. Ancak böyle durumlarda genelleştirilmiş ters matris (the generalized inverse matrix) yöntemi ile söz konusu eksiklik giderilebilir.

- STTG yönteminde kurulan ikinci modelde hata terimi bulunmaktadır. Hata terimi regresyonun varsayımlarından biri olan $\varepsilon \sim \mathrm{N}\left(0, \sigma^{2}\right)$ şeklindedir. Ancak pirinç üretim sürecinde de görüldüğü gibi gerçek dünya koşullarında bu koşul sağlanamamaktadır. Yani çoğunlukla hata terimi sabit varyanslı ve bağımsız değil kovaryansa sahip olmaktadır. Dolayısıyla bu kapsamda yapılacak çalışmalarda kurulacak modellerde hata teriminin kovaryanslı olarak incelenebilir ve katsayıların elde edilmesinde genelleştirilmiş en küçük kareler yöntemi kullanılabilir. Bu konu ile ilgili detaylar Orçanlı, Birgören ve Oktay (2017) tarafindan yapılan çalışmada bulunmaktadır.

- Yapılan çalışmada STTG katsayıları, Hotelling $T^{2}$ kontrol grafiği ile takip edilmiştir. Bu katsayılar Hotelling $T^{2}$ kontrol grafiği dişında $M E W M A$ kontrol grafiği ile de izlenebilir ve kontrol dişı sinyaller literatürde mevcut olan temel bileşenler analizi [26] veya $M Y T$ ayrıştırma [50] yöntemlerinden birisi kullanılarak çözüm getirilebilir.

- STTE ortogonal olmaması durumunda oluşabilecek çoklu bağlantı problemi çalışmada aralarında korelasyonu yüksek olan değişkenlerin birinin çıkartılması ile yeniden tanımlanmış ve çoklu bağlantı problemi giderilmiştir. Ancak bu yöntemin dişında STTG katsayıları ridge regresyonu, temel bileşenler analizi gibi tekniklerle elde edilebilir ve bu katsayıların anlamlılığının karşılaştırması yapılabilir.

- Çok değişkenli kontrol grafiklerinde kontrol dışı sinyallere neden olan değişken veya değişken gruplarını ortaya koymak için lineer olmayan modeller de uygulanabilir.

\subsection{Uygulamaya Yapılan Katkılar}

Pirinç Fabrikası üretim sürecinde önerilen modelin uygulanması esnasında pirinç alaşımının kalitesine, uygulama tekniklerine ve fabrika personeline sağladığ katkılar aşağıda sunulmuştur.

- Pirinç Fabrikası Müdürlügünde kalite kontrolü faaliyetleri kapsamında kısmi olarak uygulanan istatistiksel kalite kontrolü yöntemleri yüzde yüz olmasa da uygulanmaya başlanmıştır.

- Üretim sürecinde üretilen pirinç alaşımında değişimin varyansı düşmüştür ve kalitenin gelişmesi sağlanmıştır.
- Hurdaların harmanlanmasında ölçümleme işleminde daha hassas kantarın fabrika yönetimi tarafından satın alınarak kullanılması sağlanmıştır.

- Pirinç üretim sürecinde çalışan işçilerin farkındalıkları artmıştır.

- İşçiler tarafından vezinhaneye gelen hurdaların daha özenli olarak gruplara ayrılması sağlanmıştır.

- İşçiler ve diğer çalışanlar için eğitim programları yapılmış, uygulanmaya başlanmış ve başarılı uygulamaların yapılmaya başlandığı görülmüştür.

- Ölçümleme işleminde kullanılan stokiometrik tablolardaki değerler tekrar gözden geçirilmiş ve hatalı olarak değerlendirilen değerlerde düzeltme işlemleri yapılmıştır.

- Önerilen modelin uygulanması ile birlikte, fabrikanın kalite ve mali uzmanları ile 3 ay sonra yapılan görüşmeler neticesinde fabrikanın pirinç alaşımı satış gelirlerinde \%0.4'lük bir artışın yakalandığı belirtilmiştir.

\subsection{Gelecekte Yapılacak Çalıșmalar İçin Öneriler}

Yapılan çalışma kapsamında veya benzer konular ile ilgili gelecekte yapılabileceği değerlendirilen konular aşağıya çıkarılmıştır.

- Yapılan çalışmada, STTG katsayıları Hotelling $T^{2}$ kontrol grafiği ile izlenmiştir. Ancak söz konusu katsayılar MEWMA kontrol grafiği ile de izlenebilir. Katsayıların $M E W M A$ kontrol grafiği ile izlenmesi durumunda $M E W M A$ kontrol grafiği yönsel olarak FEWMA kontrol grafiğinde olduğu gibi "directionally invariant" özelliğine sahip olmaktadır. Dolayısıyla STTG katsayılarının izlendiği MEWMA kontrol grafiği ile $F E W M A$ kontrol grafiğinin arasında varolabilecek ortak özelliklerinin tespitine yönelik çalışmalar yapılabilir.

- Çok değişkenli kontrol grafiklerinde doğal olmayan tipik örüntüler literatürde ağırlıklı olarak tek tek ele alınmaktadır. Ancak birçok üretim sürecinde doğal olmayan tipik örüntüler değişkenler arasındaki korelasyondan dolayı ardışık olacak şekilde oluşabilmektedir (concurrent pattern). Literatürde bu çeşit ardışık örüntüler ile ilgili yapılan çeşitli çalışmalar mevcuttur, ancak yeterli değildir. $\mathrm{Bu}$ nedenle ardış1k örüntülerin tespit edilmesi ile ilgili araştırmacılar tarafından çeşitli çalışmalar yapılabilir ve uygun sınıflandırıcı modelleri önerilebilir.

\section{KAYNAKÇA}

[1] Özel, S. (2005). Çok Değişkenli Kalite Kontrol Çizelgelerinin Döküm Sanayiinde Uygulanması, (Yayımlanmamış Yüksek Lisans Tezi), Kırıkkale Üniversitesi, Fen Bilimleri Enstitüsü, Kırıkkale.

[2] Özel, S. ve Birgören, B. (2007), "Çok değişkenli kalite kontrol çizelgelerinin döküm sanayiinde uygulanması”, Gazi 
Üniversitesi Mühendislik ve Mimarlık Fakültesi Dergisi, Cilt 22(4), 809-811.

[3] Energy and Environmental Profile of the U.S. Metalcasting Industry. (1999). U.S.Department of Energy Office of Industrial Technologies.

[4] Moseki, M. (2002). "Research into melting and casting of brass scrap for upliftment purposes". Journal of the Southern African Institute of Mining and Metallurgy, 102(2), 109-114.

[5] Nur Hamizah, M. (2010). Investigation of Brass Microstructure and Mechanical Properties Using Metal Casting, (Ph.D. Thesis), Universiti Malaysia Pahang, Malaysia.

[6] Prıbulová A., Gengel’ P. ve Bartošová M. (2010). Odpady z výroby ocel'ových a liatinových odliatkov /prachy - ich charakteristika, vlastnosti a možnosti použitia, TUKE Košice.

[7] Saravanakumar, P. (2015). "A systematic approach on reducing scrap level using six sigma in Indian foundries", International Journal of Emerging Researches in Engineering Science and Technology, 2, 12.

[8] Aran, A. (2007). Döküm Teknolojileri İmal Usulleri Ders Notları, İstanbul Teknik Üniversitesi, İstanbul.

[9] Mysik, R. K., Brusnitsyn, S. V. ve Sulitsin, A. V. (2020). Determination of Thermo-Physical and Physical Properties of Complex Alloyed Brass. Solid State Phenomena, 299, 442-446.

[10] Şakar ve diğerleri (2019), Leaded brass alloys for gamma-ray shielding applications, Radiation Physics and Chemistry, 159, 64-6969.

[11] Brady, G.S. (1991). Materials Handbook: An Encyclopedia for Purchasing Managers, Engineers, Executives, and Foremen, McGraw-Hill Book Company INC, New York.

[12] Akgün, O. (2000). Pirinç Alaşımlarının Hazırlanmasında Flaksların Etkisi, (Yüksek Lisans Tezi), İ.T.Ü. Fen Bilimleri Enstitüsü, İstanbul.

[13] Mindivan, H. (2001). Yüksek Mukavemetli Pirinçlerin Mikro Yapı ve Aşınma Özelliklerine Isıl İşlemin Etkisi, (Yayımlanmamış Yüksek Lisans Tezi), İstanbul Teknik Üniversitesi Fen Bilimleri Enstitüsü, İstanbul.

[14] Sakall1, U.S. ve Birgoren, B. (2009). "A spreadsheetbased decision support tool for blending problems in brass casting industry", Computers \& Industrial Engineering, 56 (2): 724-735.

[15] Birgören, B. (2015), İstatistiksel Kalite Kontrolü, Nobel Akademik Yayıncılık, Ankara.

[16] Çolak, M. (2011). Döküm endüstrisinde ergitme endüksiyon ocakları ve spektral analiz hesaplamaları, http://www.demircelikstore.com/-1-3842-dokum-

endustrisinde-ergitme-enduksiyon-ocaklari-ve-spektralanaliz-hesaplamalari.html, Erişim Tarihi:12.10.2016.

[17] Moment Expo, (2008), Makine ve Aksamları İhracatçıları Birliği Aylık Makine İhracatı ve Ticareti Dergisi, Sayı:06.

[18] Orçanl1, K, Birgören, B. ve Oktay, E. (2018). Döküm Sanayisinde Metal Alaşım Oranlarına Hotelling $\mathrm{T}^{2}$ ve MEWMA Kontrol Grafikleri Uygulamaları. Sosyal Bilimler Araştırma Dergisi, 7 (1), 114-135
[19] Eygü, H. (2014), Çok Değişkenli İstatistiksel Kalite Kontrolünde Sıralı Küme Örnekleme Yönteminin Kullanılması: Çimento Sanayinde Bir Uygulama, (Yayımlanmamış Doktora Tezi), Atatürk Üniversitesi Sosyal Bilimler Enstitüsü, Erzurum.

[20]Alt, F.B. (1985). Multivariate Quality Control, The Encyclopedia of Statistical Sciences, Wiley, New York, 110122.

[21] Montgomery, D.C. ve Wadsworth, H.M. (1972), Some Technques for Multivariate Quality Control Applications. In ASQC Technical Conference Transactions, Washington.

[22] Alt, F.B. ve Smith, N.D. (1988), Multivariate Process Control. In Handbook of Statistics (eds.P. R. Krishnaiah and C. R. Rao), 333-351. Elsevier.

[23] Lowry,C.A., Woodall, W.H., Champ, C.W. ve Rigdon, S.E., (1992), "A multivariate exponentially weighted moving average control chart", Technometrics, 34(1), 46-53. [24] Reynolds, M. R. ve Cho, G. (2006), "Multivariate control charts for monitoring the mean vector and covariance matrix". Journal of Quality Technology 38(3), 230-253.

[25] Hotelling, H. (1947). Multivariate Quality Control, Illustrated by the Air Testing of Sample Bombsights, in Techniques of Statistical Analysis, Mc-Graw Hill, New York.

[26] Montgomery, D.C. (2013). Introduction to Statistical Quality Control (6th Edition), John Wiley, New York.

[27] Runger, G.C. (1996), "Projections and the $U^{2}$ Multivariate Control Chart.” Journal of Quality Technology 28(3), 313-319.

[28] Barton, R.R., ve Gonzalez-Barreto, D.R. (1996). "Process oriented basis representations for multivariate process diagnostics", Quality Engineering, 9, 107-118.

[29] Mantripragada, R. ve Whitney, D.E. (1999), Modeling and Controlling Variation Propagation in Mechanical Assemblies Using State Transition Models. IEEE Transactions on Robotics and Automation 15(1), 124-140.

[30] Jin, J. ve Shi, J. (1999). "State space modeling of sheet metal assembly for dimensional control", Journal of Manufacturing Science and Engineering-Transactions of the ASME, 121(4), 756-762.

[31] Ding, Y., Ceglarek, D. ve Sh1, J. (2000). "Modeling and Diagnosis of Multistage Manufacturing Processes: Part I: State Space Model." In Japan/USA Symposium on Flexible Automation, Ann Arbor, Michigan, JUSFA-13146.

[32] Zhou, S., Huang, Q. ve Sh1, J. (2003), "State Space Modeling of Dimensional Variation Propagation in Multistage Machining Process Using Differential Motion Vectors". IEEE Transactions on Robotics and Automation 19(2), 296-309.

[33] Djurdjanovic, D. ve N1, J. (2001).’Linear State Space Modeling of Dimensional Machining Errors". Transactions of NAMRI/SME XXIX, 541-548.

[34] Huang, Q.. Zhou, N. ve Sh1, J. (2000), Stream of Variation Modeling and Diagnosis of Multistation Machining Processes. American Society of Mechanical Engineers, Manufacturing Engineering Division, MED 11, 81-88.

[35] Espada Colon, H.I. ve Gonzalez-Barreto, D.R. (1997). "Component registration diagnosis for printed circuit boards 
using process-oriented basis elements", Computers and Industrial Engineering, 33, 389-392.

[36] Gong, L., Jwo, W. ve Tang, K. (1997). "Using on-line sensors in statistical process control", Management Science, 43, 1017-1028.

[37] Singh, R. ve Gilbreath, G. (2002). "A real-time information system for multivariate statistical process control", International Journal of Production Economics, 75, 161-172.

[38] Koçer, B. ve Birgören, B . (2010). Approaches For Problem Diagnosis Via Statistical Process Control Charts . Gazi University Journal of Science , 17 (4) , 59-69.

[39] Montgomery, D. C. (2009). Introduction to Statistical Quality Control (5th Edition) John Wiley, New York.

[40] Runger, G.C., Barton, R.R., del Castillo, E. ve Woodall, W.H. (2007). "Optimal monitoring of multivariate data for fault patterns", Journal of Quality Technology, 39(2), 159172.

[41] Apley, D.W. ve Shi, J. (1998). "Diagnosis of multiple fixture faults in panel assembly", ASME Journal of Manufacturing Science and Engineering, 120, 793-801.

[42] Lee, H.Y. ve Apley, D.W. (2004). "Diagnosing manufacturing variation using second-order and fourth-order statistics". International Journal of Flexible Manufacturing Systems, 16, 45-64.

[43] Yang, K., He, Y. ve Xie, W. (1994). "Statistical diagnosis and analysis techniques: a multivariate statistical study for an automotive door assembly process". Quality Engineering, 7, 1-29.

[44] Ceglarek, D., Shi, J. ve Wu, S.M. (1994). "A knowledge-based diagnostic approach for the launch of the auto-body assembly process", Journal of Engineering for Industry, 116(4), 491-499.

[45] Mason, R.L. Chou, Y.M. ve Young. J.C. (2001). "Applying Hotelling's $T^{2}$ statistic to batch processes", Journal of Quality Technology, 33, 466-479.

[46] Stoumbos, Z.G., Reynolds, M.R., Ryan, T.P. ve Woodall, W.H. (2000). "The state of statistical process control as we proceed into the 21 st century, Journal of the American Statistical Association, 95, 992-998.

[47] Fuchs, C., ve Kenett, R.S. (1998). Multivariate Quality Control: Theory and Applications, Marcel Dekker, New York.

[48] Murphy, B.J. (1987). "Selecting out of control variables with the $\mathrm{T}^{2}$ multivariate quality control procedures", The Statistician, 36: 571-583.

[49] Doganaksoy, N., Faltin, F.W. ve Tucker, W.T. (1991), "Identification of out of control quality characteristics in a multivariate manufacturing enviroment", Communications in Statistics-Theory and Methods, 20(9), 27-75.

[50] Mason, R. L., Tracy, N. D. ve Young, J. C. (1995). "Decomposition of $\mathrm{T}^{2}$ for multivariate control chart interpretation", Journal of Quality Technology, 27(2), 991108 .

[51] Nedumaran, G. ve Pignatiello, J.J. (1998). "Diagnosing signals from $\mathrm{T}^{2}$ and $\chi^{2}$ multivariate control charts", Journal of Quality Engineering, 10, 657-667.
[52] Birgören, B. (2000). "Çok boyutlu kalite kontrolde T² sinyallerinin scheffe tipi aralıklarla yorumlanması", İstatistik Sempozyumu, Bildiriler Kitab1, 347-358.

[53] Maravelakis, P. E., Bersimis, S., Panaretos, J. ve Psarakis, S. (2002). "Identifying the out of control variable in multivariate control", Communications in StatisticsTheory and Methods, 31: 2391-2408.

[54] Mason, R.L., Chou, Y.M., Sullivan, J.H., Stoumbos, Z.G. ve Young, J.C. (2003). "Systematic patterns in $\mathrm{T}^{2}$ charts", Journal of Quality Technology, 35, 47-58.

[55] Orçanlı K., Oktay E. ve Birgören B. (2017). "The Effects of Covariance Over the Residuals of Process Oriented Basis Representation in Mulivariate Quality Control", Social Sciences Research Journal, 6 (2), 20-40.

[56] Apley, D.W. ve Lee, H.Y. (2003). "Simultaneous identification of premodeled and unmodeled variation pattern", Journal of Quality Technology, 42(1), 36.

[57] Apley, D. W. ve Shi, J. (2001). "A factor-analysis method for diagnosing variability in multivariate manufacturing processes". Technometrics, 43, 84-95.

[58] Jin, N. ve Zhou, S. (2006). "Data-driven variation source 1dentification of manufacturing processes based on eigenspace comparison", Naval Search Logistics, 55:383396.

[59] Ding, Y., Gupta, A. ve Apley, D. (2004). "Singularity 1ssues in fixture fault diagnosis for multi-station assembly systems", ASME Journal of Manufacturing Science and Engineering, 126, 200-210.

[60] Huang, Q. ve Shi, J. (2004). "Variation transmission analysis and diagnosis of multi-operational machining processes". IIE Transactions on Quality and Reliability, 36, 807-815.

[61] Birgören, B. (1998). Multivariate Statistical Process Control for Quality Diagnostics and Applications to Process Oriented Basis Representations, (Ph.D. Thesis), PennState University, Pennsylvania.

[62] Birgören, B. (2004), "A method for problem diagnosis in multıvarıate quality control: constrained solution spaces for process oriented basis representatıons", Teknoloji, 7(1), 19-28.

[63] Colon, E. (1998) “Component registration diagnosis for printed circuit boards using process-oriented basis elements, Computers and Industrial Engineering, 33, 389-392.

[64] Padilla, V.O. (2005), Process Oriented Basis Estimation in Presence of Non-orthogonal Basis Elements, (Master Thesis), University of Puerto Rico, Puerto Rico.

[65] Schmitt A.J., Marcus, A. ve Barton R. (2002). "Benefit analysis of process-oriented basis representation as a method of multivariate statistical process control". IIE 2002, Conference Proceedings.

[66] Barton, R.R. ve Gonzalez-Barreto, D.R. (1999). "Process-oriented basis representations: linking manufacturing process design and diagnosis", Proc. Euro. Conf. Con. Eng., 9, 109-114.

[67] Montgomery, D.C., Peck, E.A. ve Vining, G.G. (2012). Introduction to Linear Regression Analysis, John Wiley \& Sons, New York.

[68] Orçanlı, K. (2017), Çok değişkenli Kontrol Grafikleri ve Yapay Sinir Ağları ile Döküm Sanayinde Bir İstatistiksel 
Süreç Kontrolü, Yayımlanmamış Doktora Tezi, Atatürk Üniversitesi Sosyal Bilimler Enstitüsü, Erzurum.

[69] Hoerl, A.E. ve Kennard, R.W. (1970). "Ridge regression: Biased estimation for nonorthogonal problems", Technometrics, 12, 55-67.
[70] Gunst, R.F. ve Mason, R.L. (1997). "Biased estimation in regression: An evaluation using mean squared error", Journal of the American Statistical Association, 72(359), 616-628. 